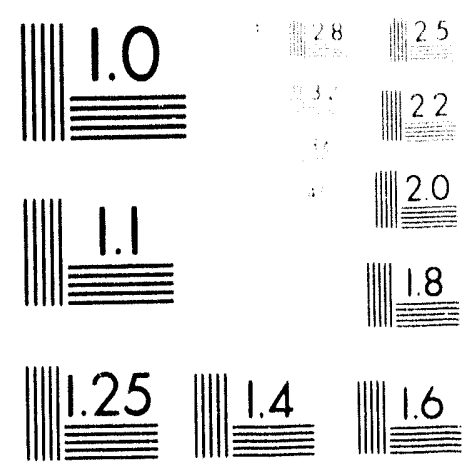



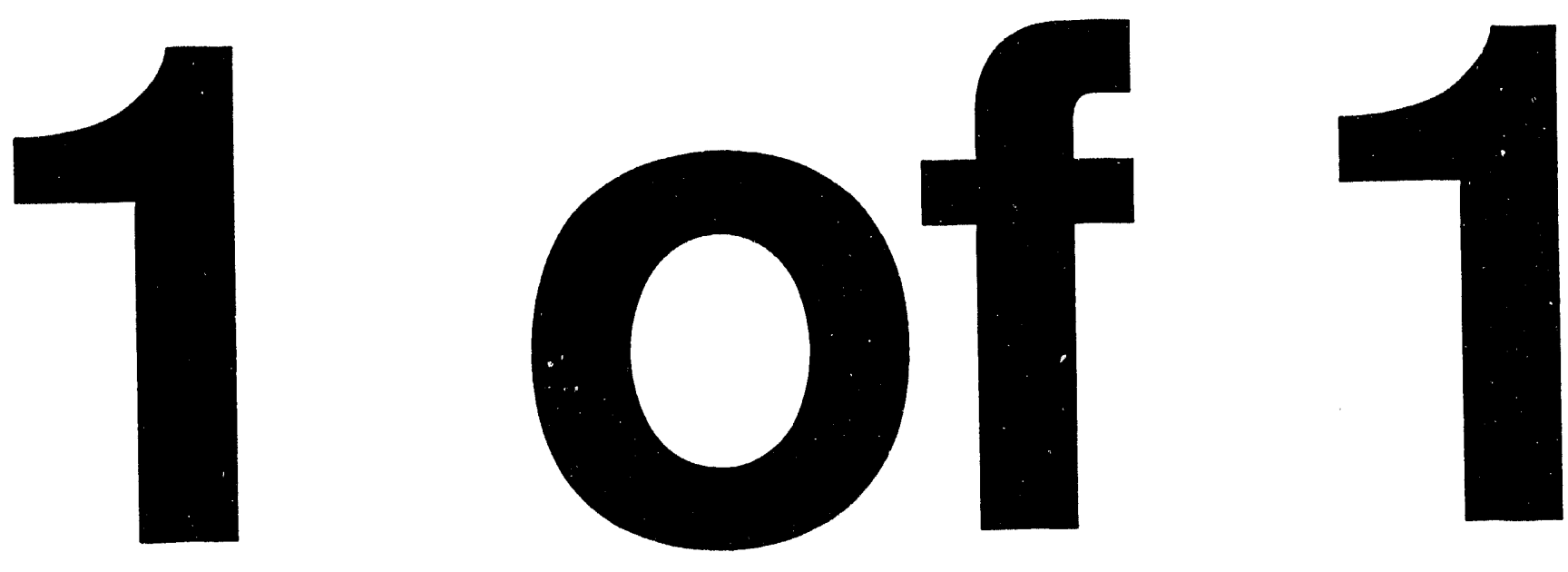
SAND93 2156

Unlimited Release

Printed September 1993

Distribution

Category UC 706

\title{
Autocharacterization Feasibility System On Ilunters Trophy Event
}

\author{
Richard A. Mills \\ Instrumentation Development Department 9321 \\ Sandia National Laboratories \\ Albuquerque, NM 87185
}

\begin{abstract}
An automated system to characterize cable systems at NTS has been developed to test the feasibility of such a system. A rack of electronic equipment including a fast pulse generator, digital sampling scope, coaxial switch matrix and GPIB controller was installed downhole at NTS for the Hunters Trophy event. It was used to test automated characterization. Recorded measurements of simulation and other instrument data were gathered to determine if a full scale automated system would be practical in full scale underground nuclear effects tests. The benefits of such a full scale system would be fewer personnel required downhole; more instrument control in the uphole recording room; faster acquisition of cable parameter data.
\end{abstract}

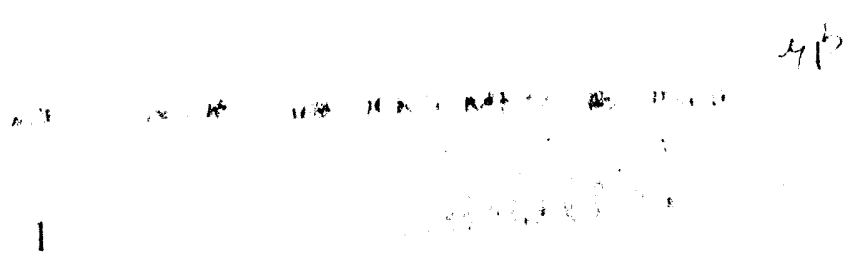




\section{Table of Contents}

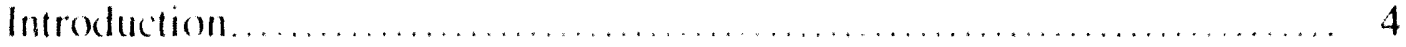

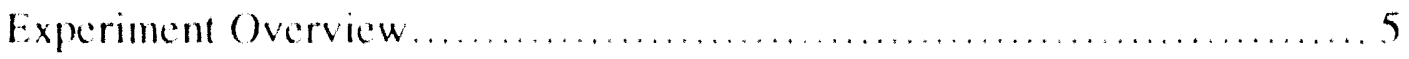

Hardware Description......................................... 7

Simulation Measurements Results.............................. 11

Software Description......................................... 21

Pulse Generator Measurement ................................. 22

Characterization Measurement .................................... 23

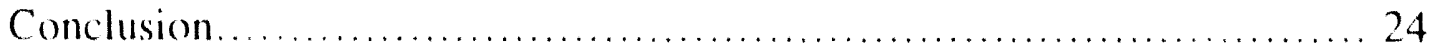

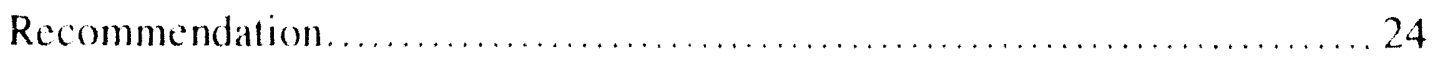

Figures

I System Block Diagram..................................... 6

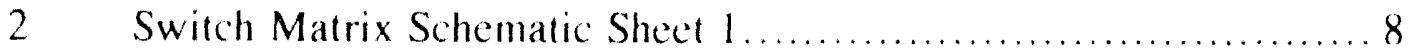

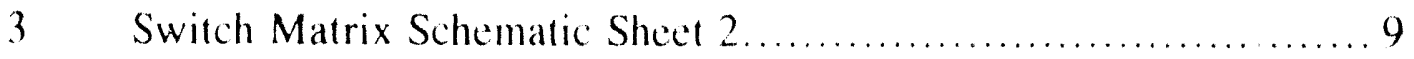

4 HP3488A Configuration.................................... 10

$5 \quad$ Fast Pulse Generator Signal Path........................... 12

6 Fast Pulse Generator Plot.................................. 13

7 Fast Pulse Generator to UHC Signal Path....................... 14

8 Simulation Generator Signal Path For Recording................. 15

9 Plots of Simulation Data Recorded from Uphole.................. 16 - 20

10 Fast Pulse Generator Pulse Recorded Uphole.................... 23 
Tables

Autocharacterization Control Menu. 5

\section{Abbreviations}

$\begin{array}{ll}\text { COM } & \text { COMmon } \\ \text { GEN } & \text { GENerator } \\ \text { GPIB } & \text { General Purpose Interface Bus } \\ \text { NS } & \text { NanoSecond } \\ \text { NTS } & \text { Nevada Test Site } \\ \text { PPL } & \text { Picosecond Pulse Lab } \\ \text { PS } & \text { PicoSecond } \\ \text { SW } & \text { SWitch } \\ \text { TEK } & \text { TEKtronix } \\ \text { UGT } & \text { UnderGround Test } \\ \text { UHC } & \text { UpHole Cable }\end{array}$




\subsection{INTR(O)I ( TIO)}

This report describes an atutemated full resordeng system and able chardeterization

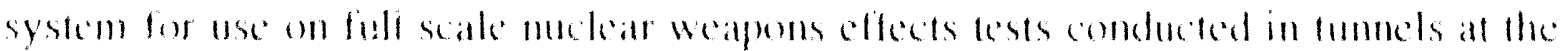
Nevada Test Site (NTS) Signals from high frequency diagnostics are routed from underground ganges to an abovegroumd data rocording lacility at NTS in area 12. Bldg. 12.909. via shom copper coax cables and a $7 \mathrm{~km}$ andog fiber optic link. A small kasibility system was developed and kested on the Hunters Trophy event duning Alegust and Sepromber, 1992.

The proess of thataterishg cable systems at NTS for GGT experments requires

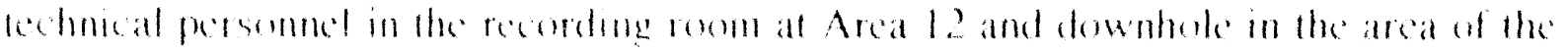

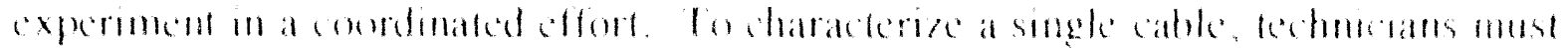

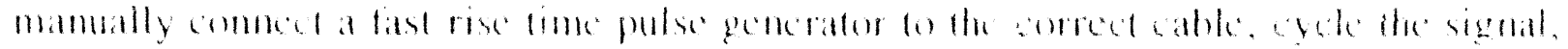

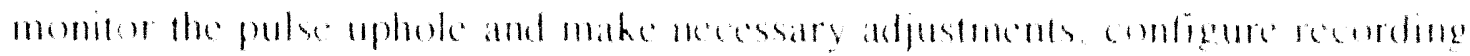

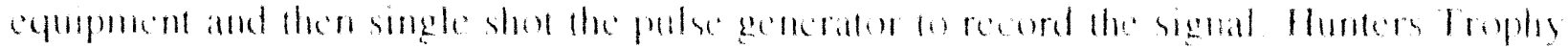

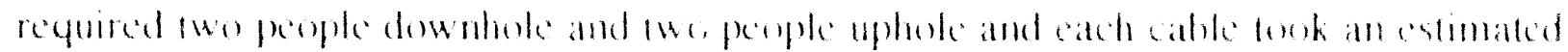
hall hour to 15 mimules 10 compllete

Buring the dry run period, ihe signal simulation system smombancously pulses all cathles. After intial selup). the configuration is hept in place until atelual connection to a gatage. Pertodic dhatacterization of simulation is desired to monitor drift of fiber optic lasers and other system components. This requires discomnectung the able from the simulation generator and reconnecting the generator fo a sampling scope to accurately record the inpul signal. Sumblation monitoring gives information on drift of the fither optic lascrs and racks $k$ factors.

Autcharacterization is an attempt fo atumate the process of characterisation and combine simulation as well. By automating and combining the two processes. less personnel would be required the time downthole would be redeced. wear on cable connectors would be reduced. the probability of error in comecting cables wouk be reduced and simulation pulser outputs combl be chatacteriad mote often. possibly daily.

A fully antomated system to charackerie and simulate cable systems would eventually run on a workstation with multiwindow capability under control of an operator. 


\subsection{IXPLRINANT OVERUILW}

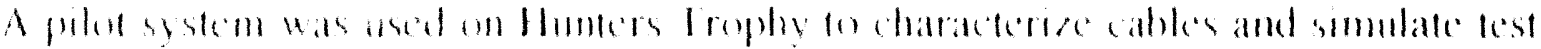

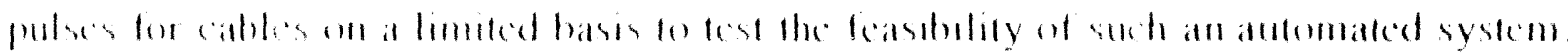

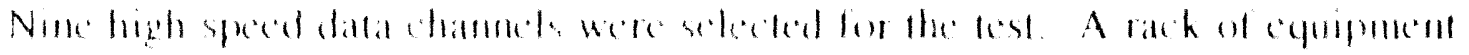

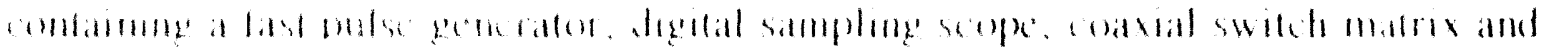

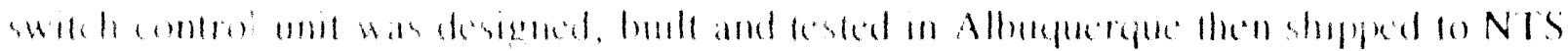

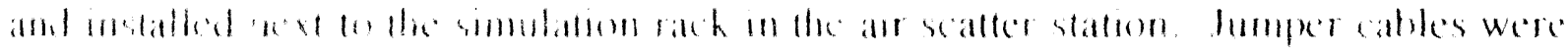

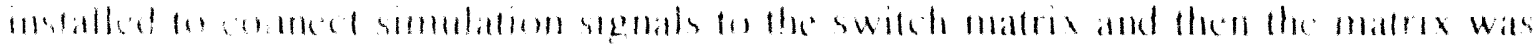

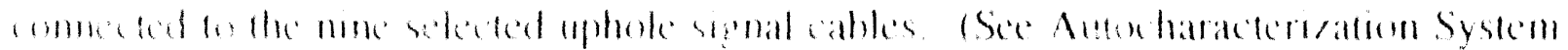

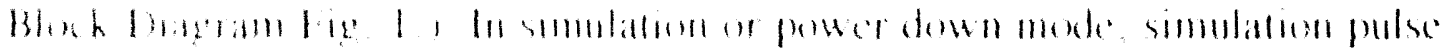

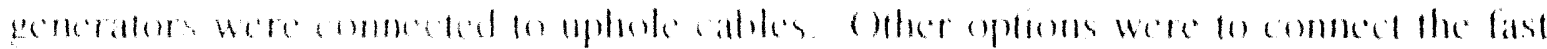

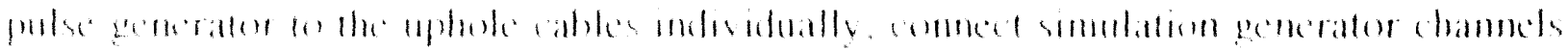

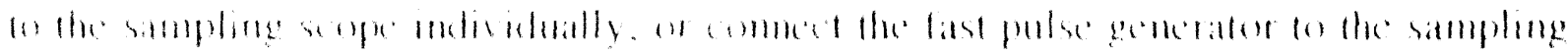

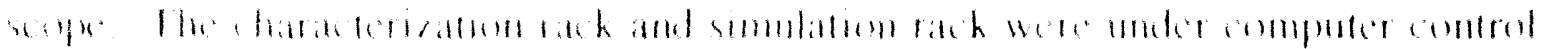

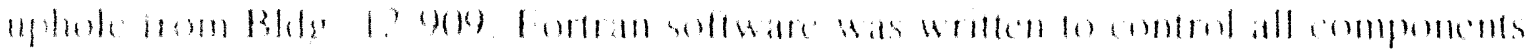
riments

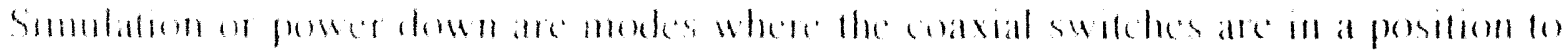

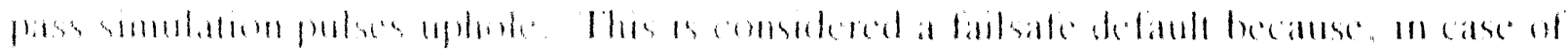

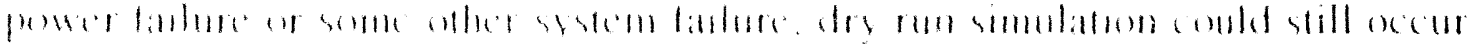

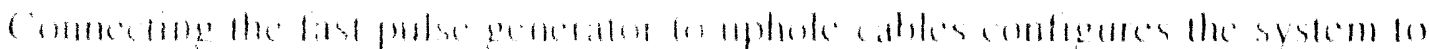

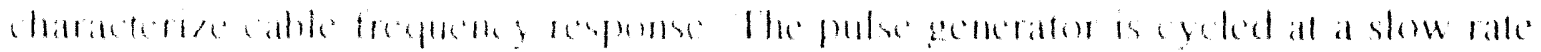

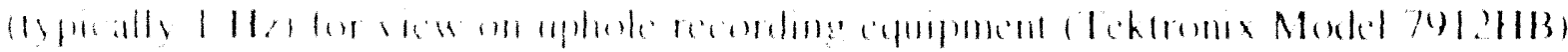

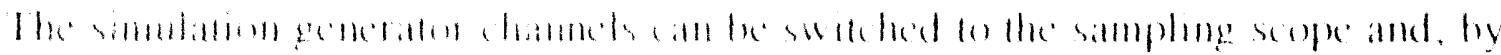

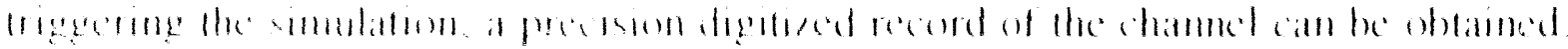

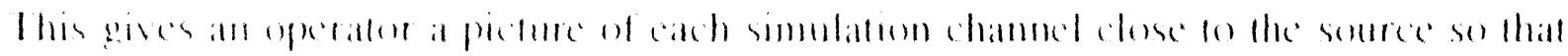

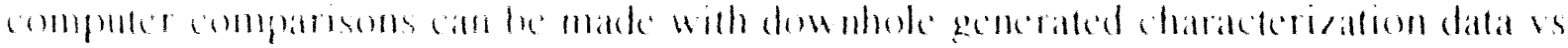

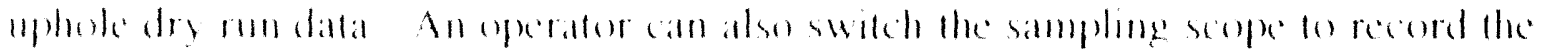

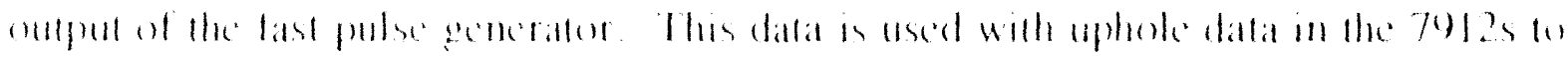

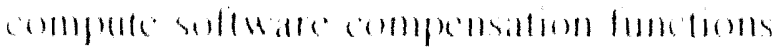

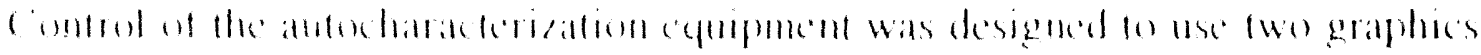
termmals. One lemonal is ased fo control the swith matrix and ofher instruments and

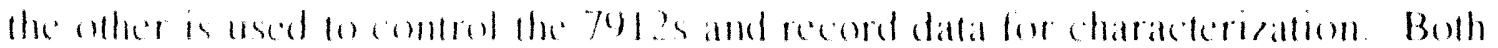
kermmals would be plated sek by sike for ease of use. A more mature system wouk

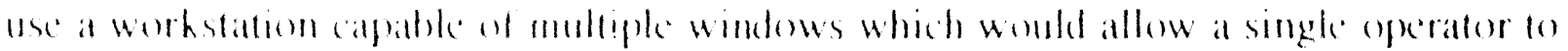

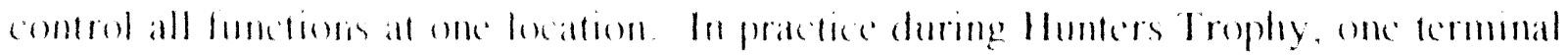

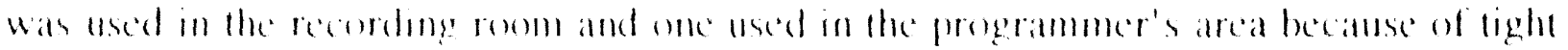
calihallon and dry rom setheduling. 


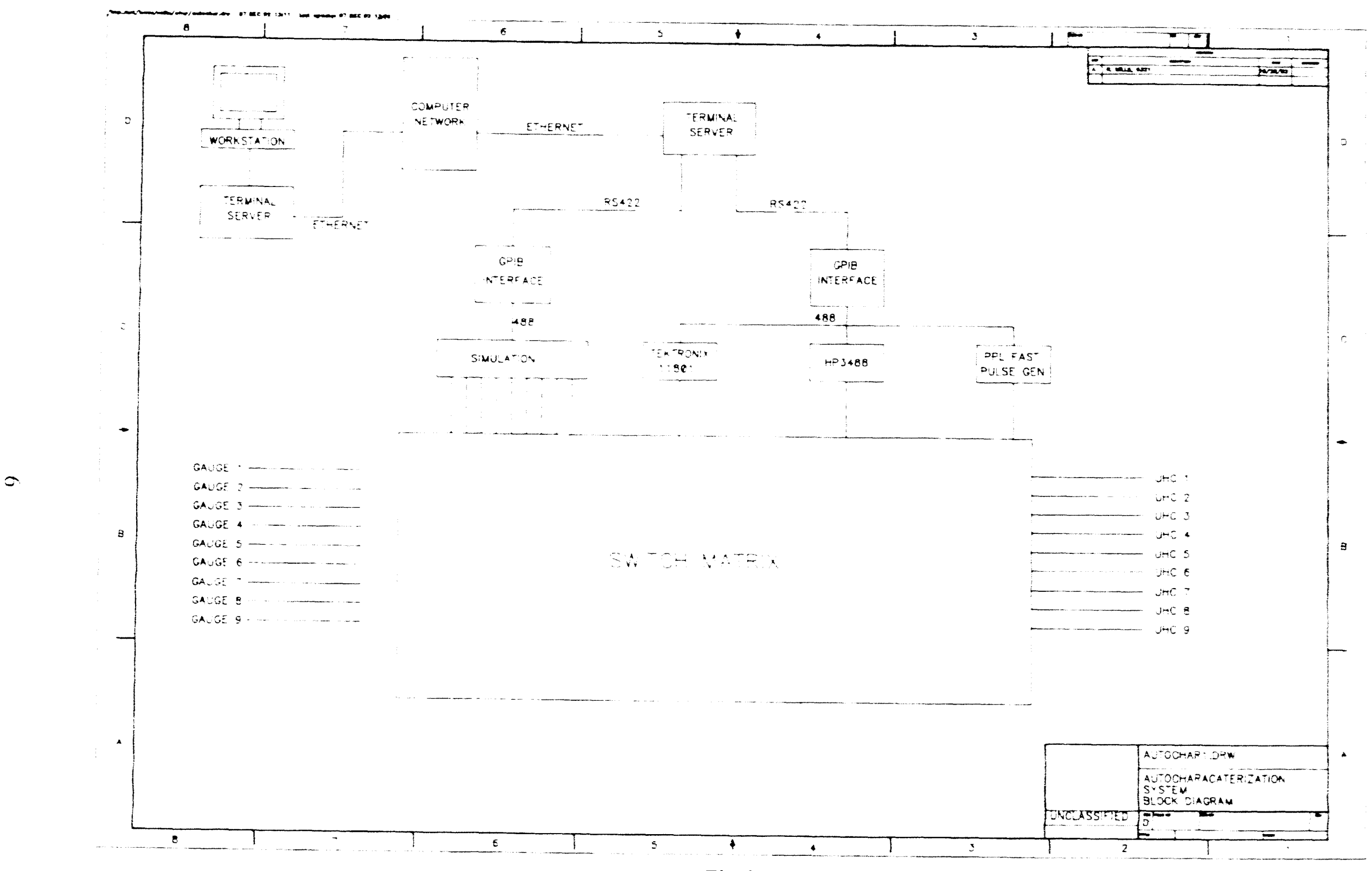

Fig 1

Autocharacterization system block diagram. Hunters Trophy used two terminals instead of the workstation shown. 


\subsection{IIARIOWARE IOES( 'RIPIION}

The bleck deagram of the Autochataterization System (Fig. 1) shows how the major components are commected together. The components affer the Terminal Server and except the simulation block, were leated in the short characterization rack next to the simulation rack in the seatler station. After characterization and simulation were complete. the whole system was disconnected and sent uphole. The gauges in the diagram were then connected to the uphole cables (UHC I UHC 9) for actual event recording

The Autucharacterization Switch Matrix Schematic (Fig. 2,3) details the coaxial switches for routing fast pulses. In the simulation or power down mode, the switches are as shown in the schematic drawing. The diodes in the switch matrix control circuit form OR functions that allow grouping of the coaxial switches. For example, when HARG is connected 10 common, SWLY3, SW2 Y6 and SW/4 are closed. This signal path sends the pulse generator signal to uphole cable UHC 6 and requires only one HP3488A relay closure and one computer instruction. This economizes the use of the HP $3488 A$ and simplifies the soliware SIMSIGI SIMSIG9 are simulation signals from the smolation rack and WHCI UHCO are uphole cables. HARO HERG control relay dosures and come from the HP3488A. The HP3488A conliguration schematic (Fig. 4) details how the HP3488A is set op and comecked to the switch matrix for control

The Pulse Cienerator Signal Path Sohematic (lige. 5) shows the path from the fast pulse generater to the Tektronix $|1,80|$ sampling seope. This is critical in verifying the pulses sent uphole are correct in amplitude and duration. The schematic shows how many and what kind of enaxial switches are used. fig. 6 is a plot of a one volt, $50 \mathrm{~ns}$ pulse through this path thall was observed in the lab betore the system was installed After installation. similar signal plose were reourded to verify connections. The pathway in the Characterization Schematic (Fig. 7) shows the fast pulse generator connected to an uphole cable. This moke is used in acquiring data for calculating $k$ factors

The Simulation Generator se hematic (Fig. 8) shows the path from a simulation generator to an uphole cable.

Fig. 9a thromgh Fig. 9i are plots comparing recorded dala from the simulation generator as shown in Fig. 8 with recorded data of the 11801 manually connected to the UHC output. The objective is 10 see the difference in the signal between SW27. SW9 and SW27. SW6, SW5,SW45. The resule gives a pictorial display of the accuracy of the plots taken downhole of simulation 


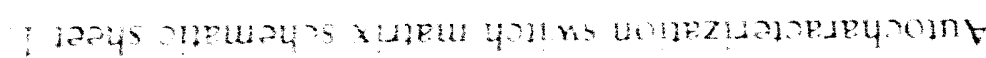

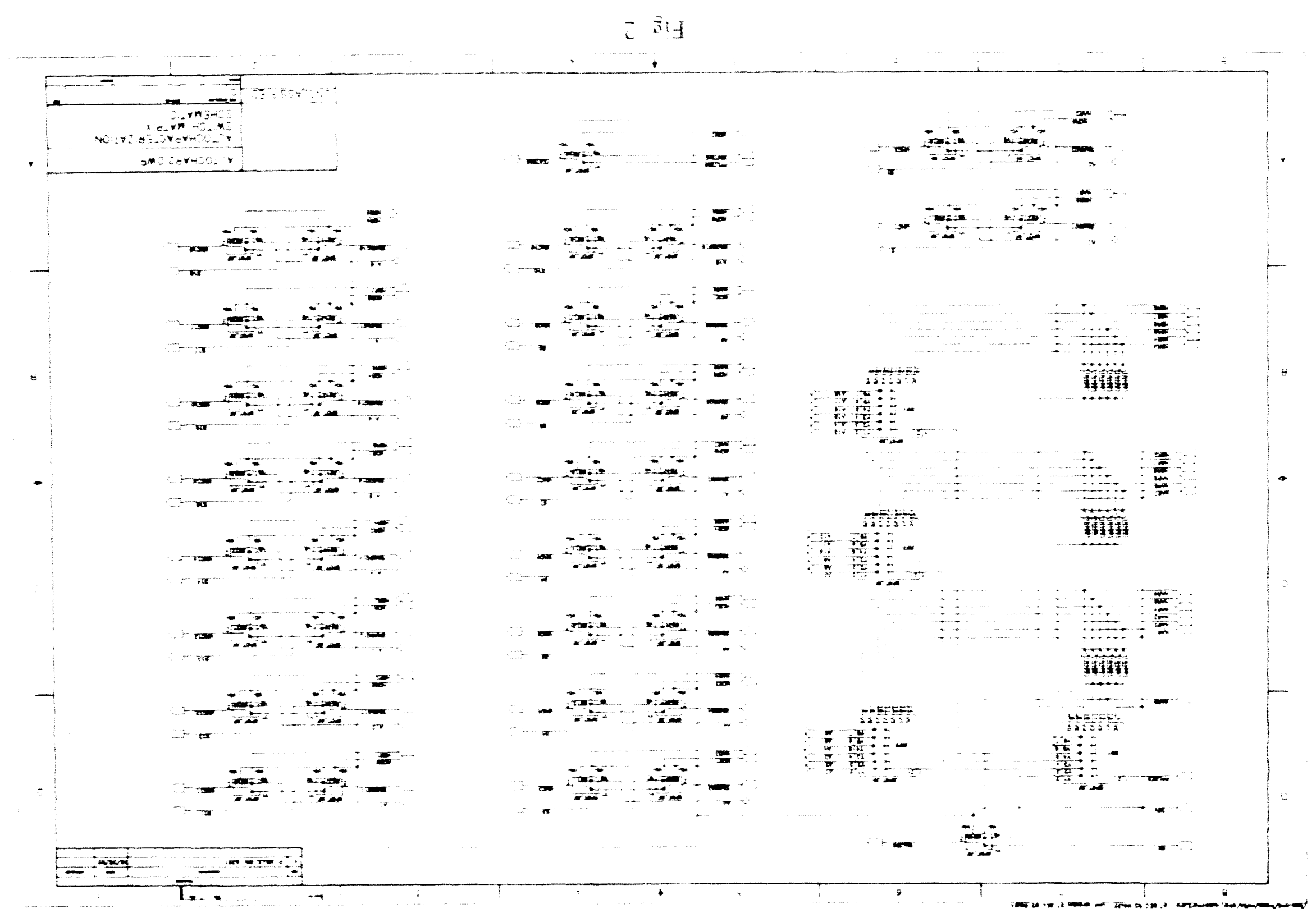




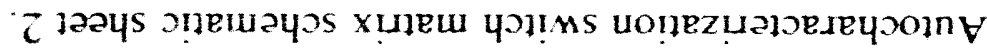

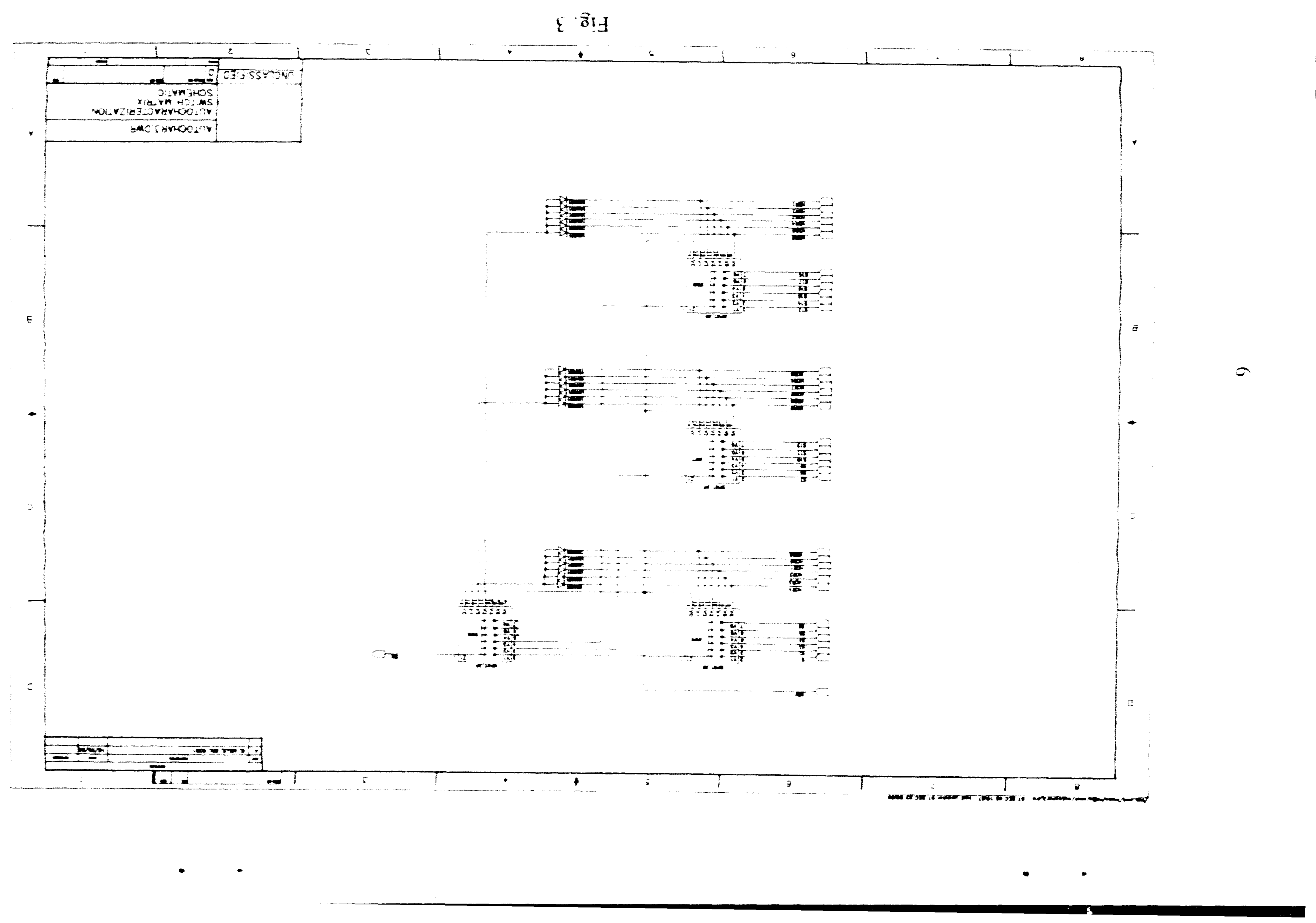




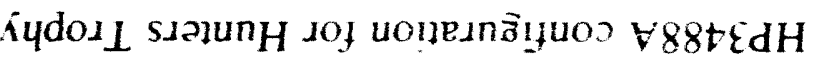

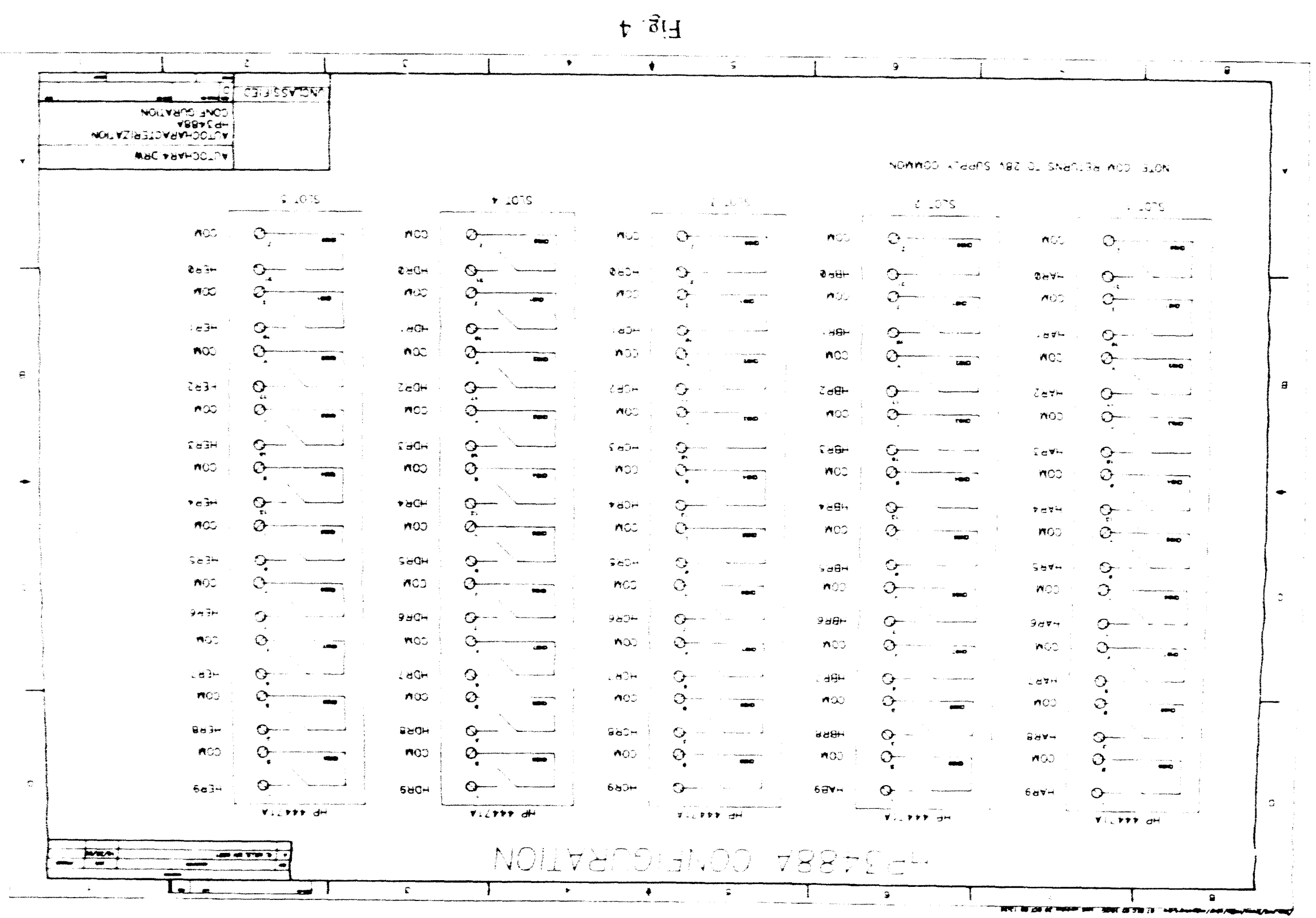




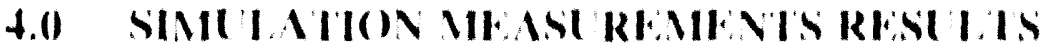

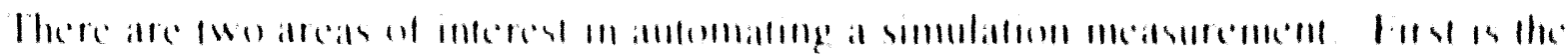

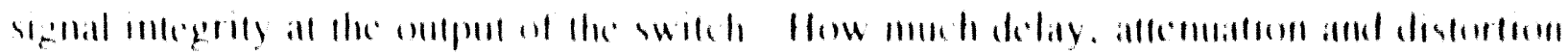

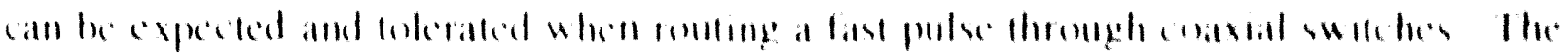

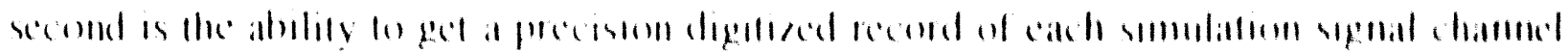

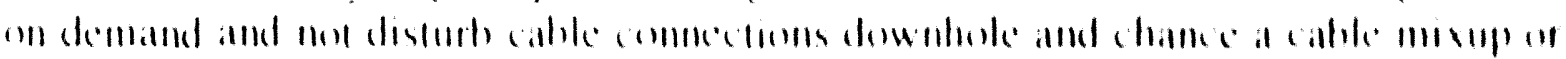

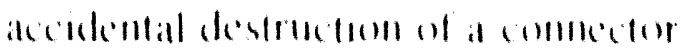

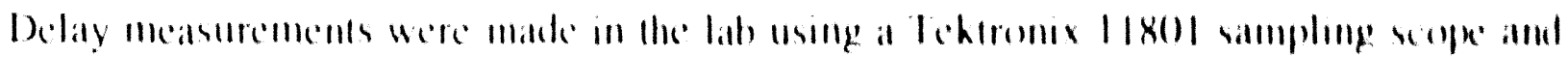

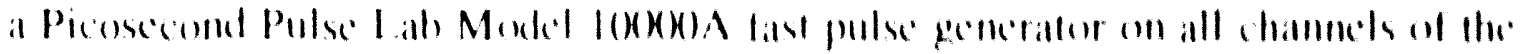

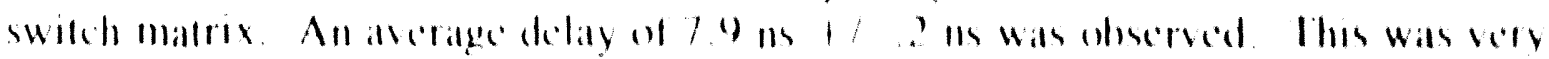

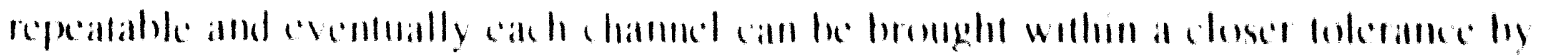

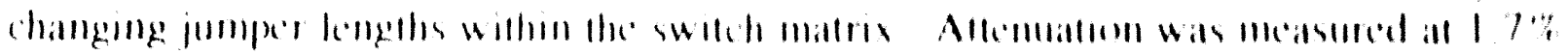

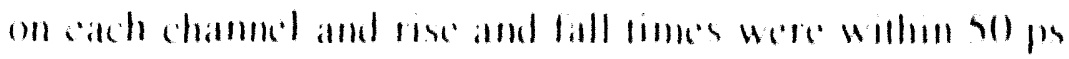

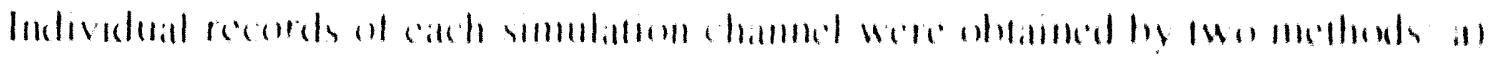

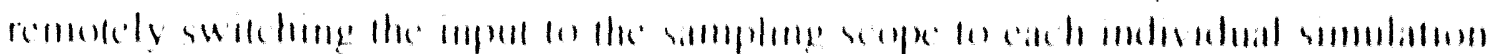

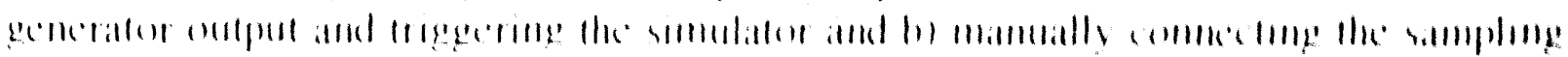

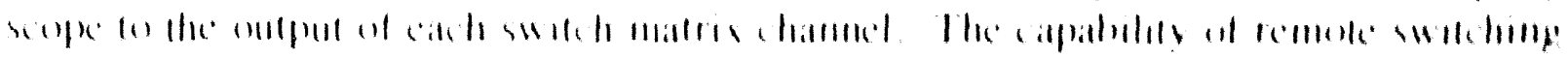

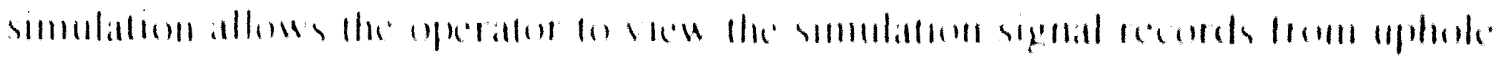

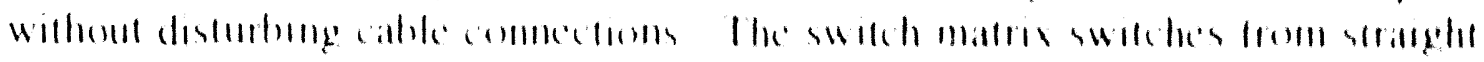

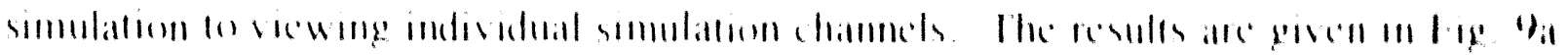

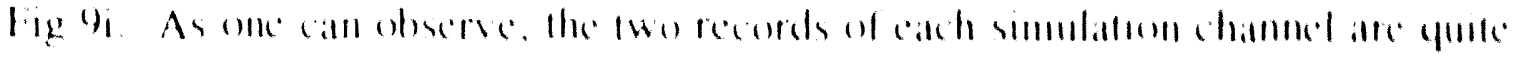

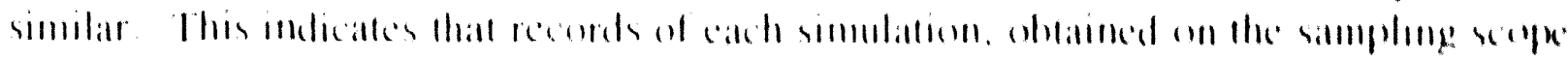

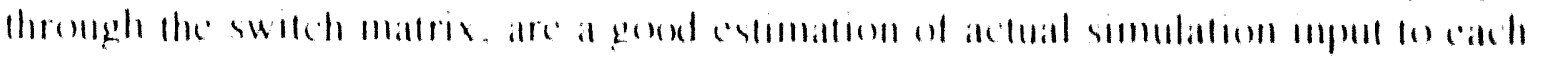

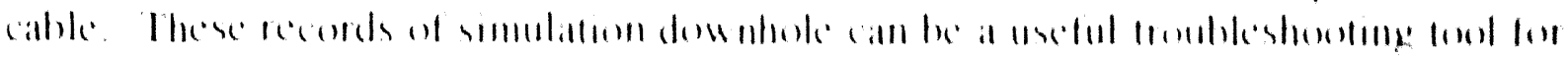
(1) valtors. 


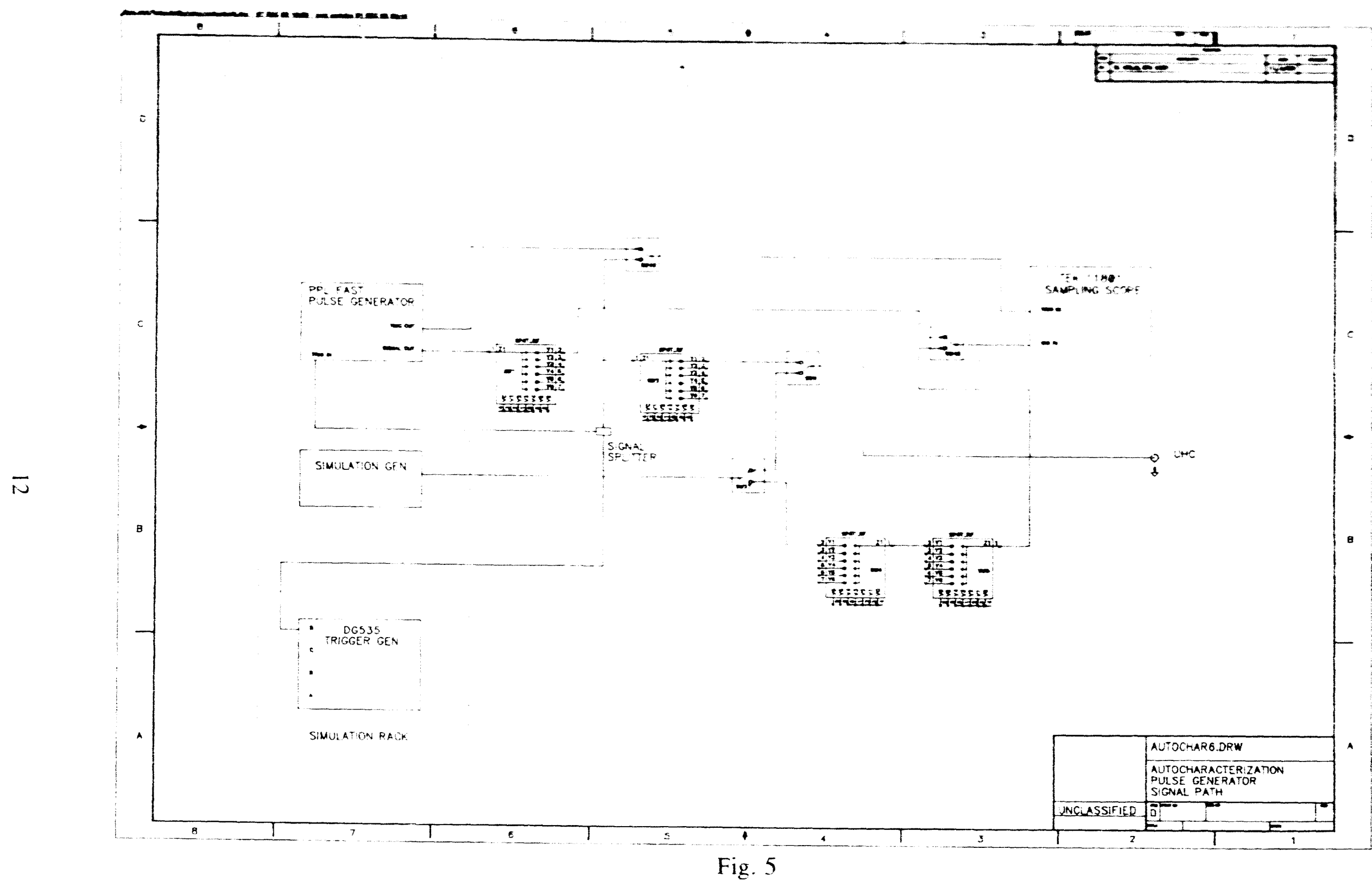

Fast Pulse Generator signal path to Tektronix 11801 sampling scope. 


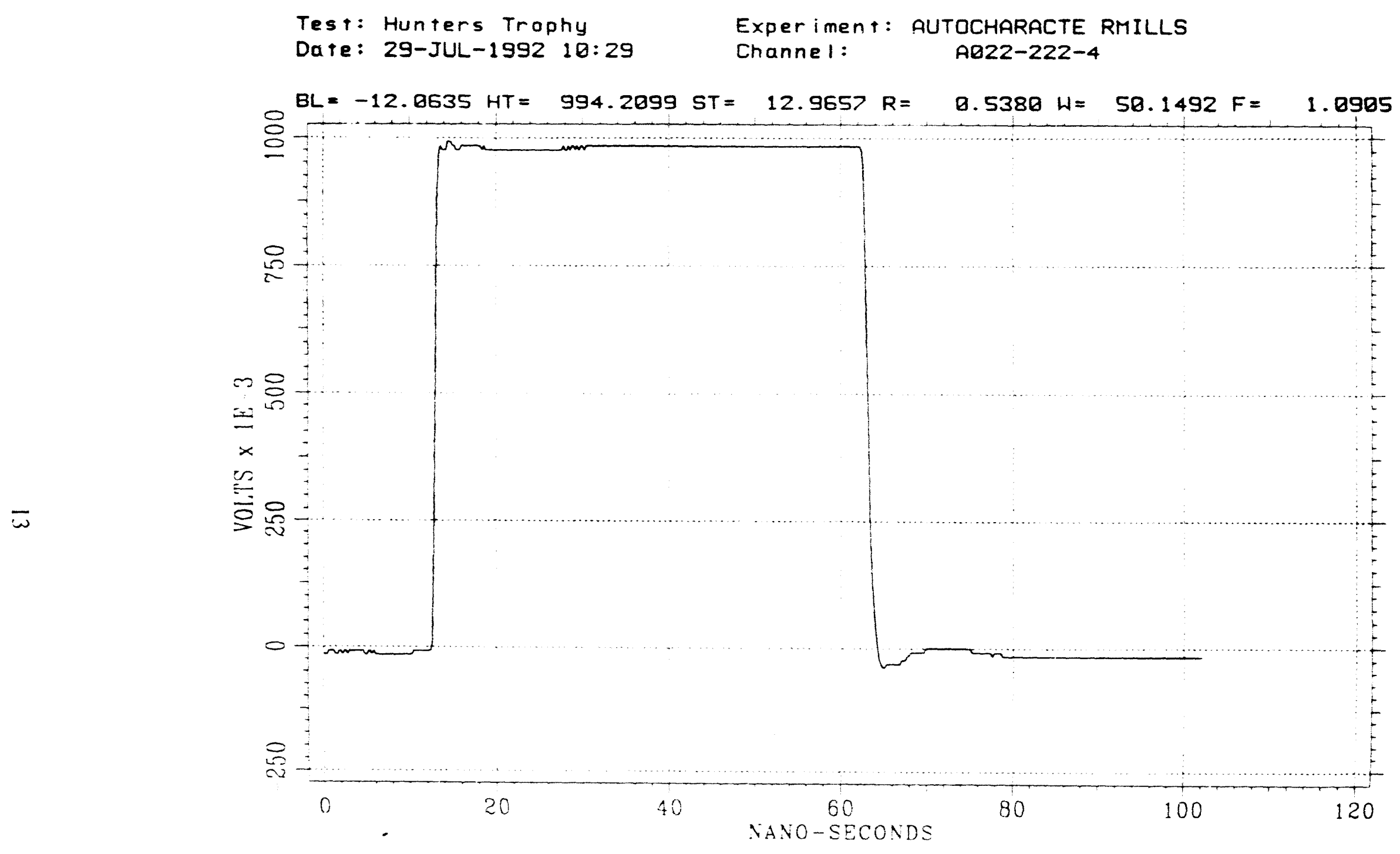

Fig. 6

Fast Pulse Generator output recorded through switch matrix. 


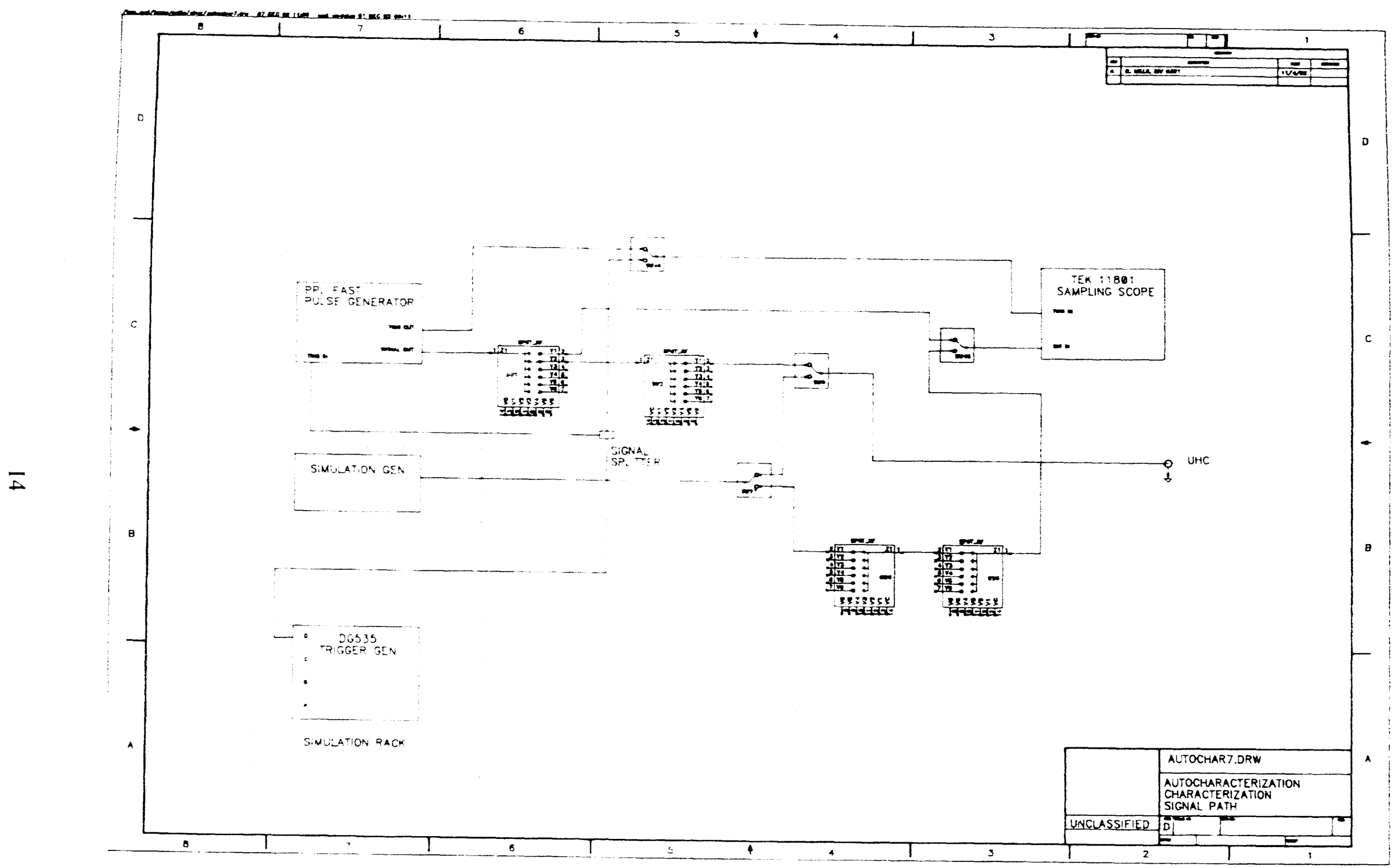

Fig. 7

Fast Pulse Generator switched to an uphole cable (UHC). This signal path is used to characterize each uphole cable system. 


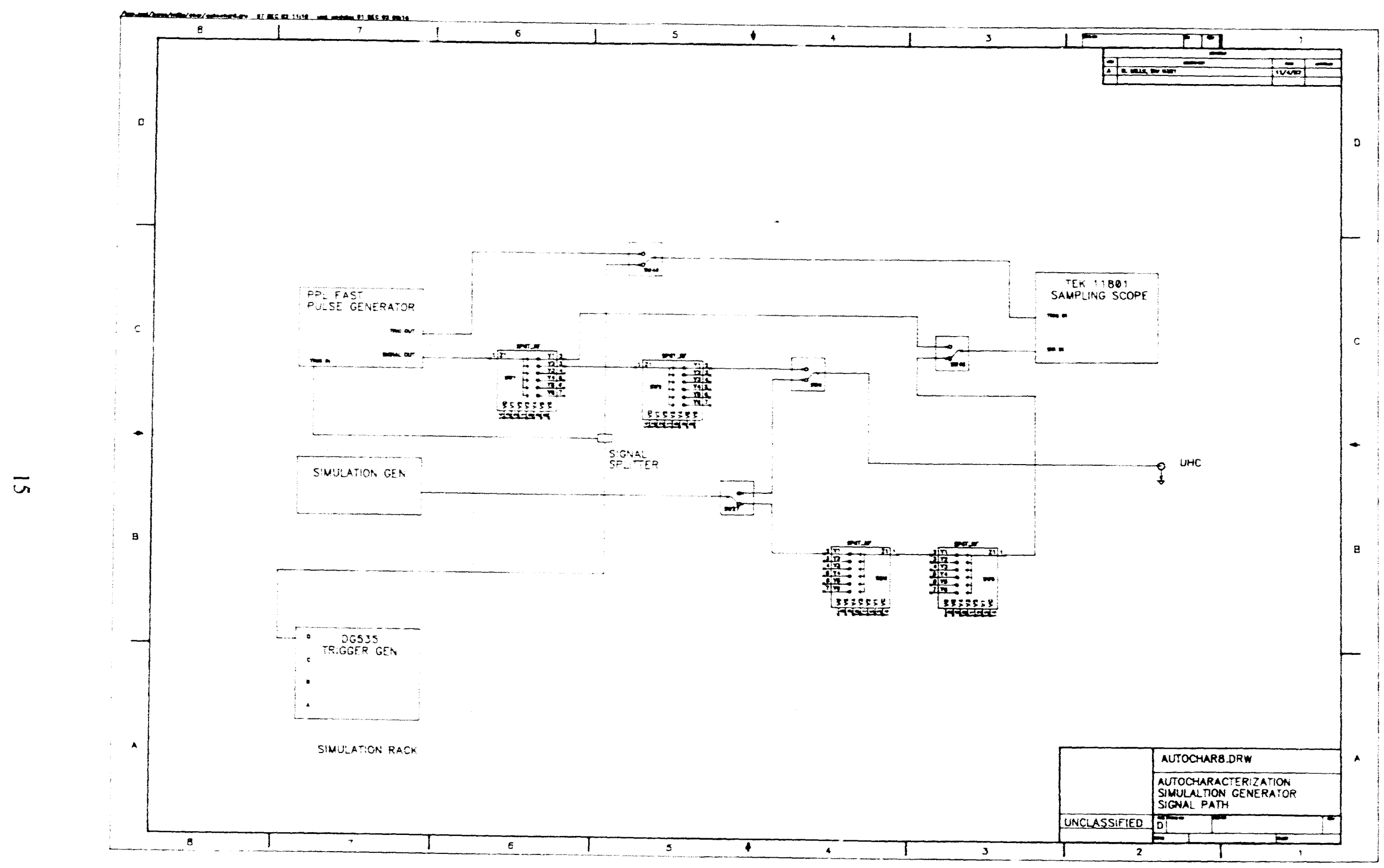

Fig. 8

Signal path for recording simulation generator data from uphole. 


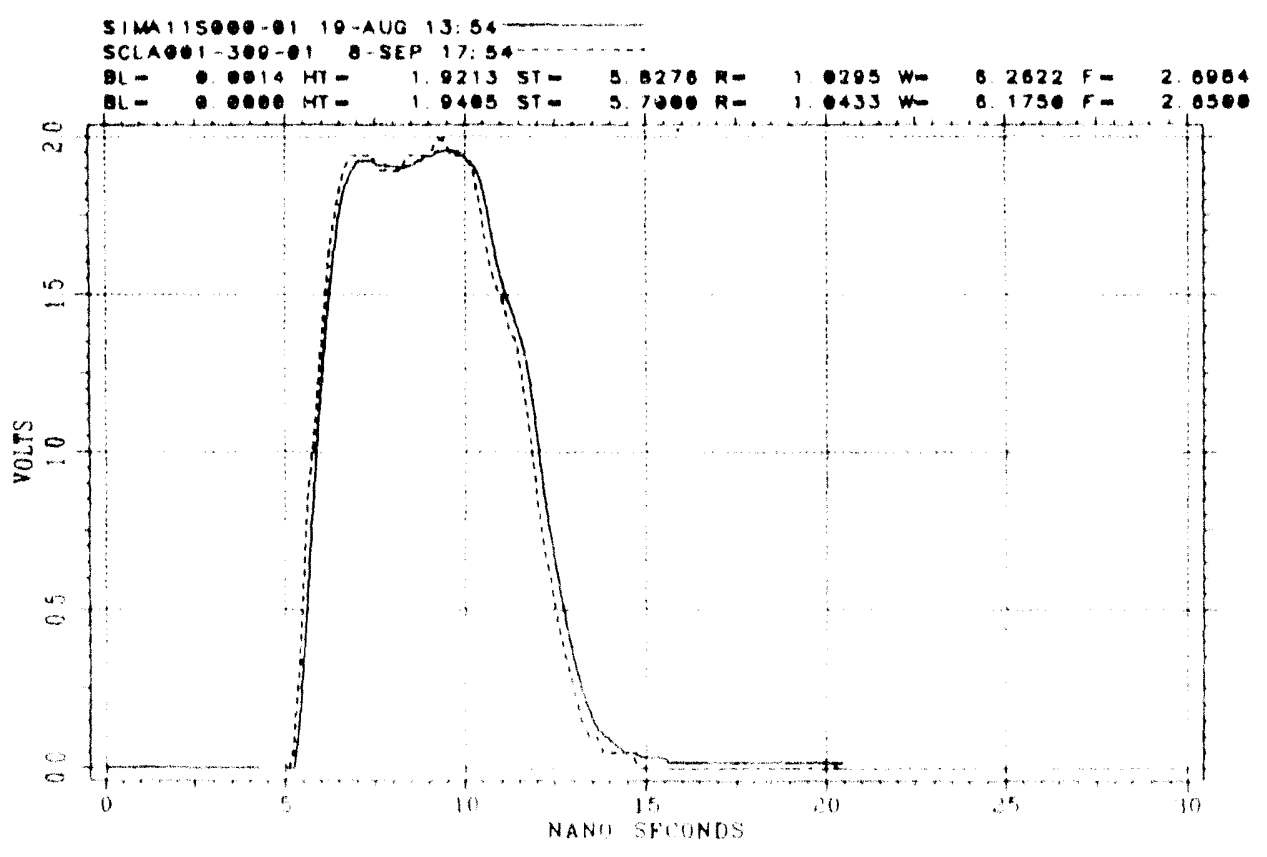

fig. 9 a.

Simulation channel I recorded hrough the switch matrix. Dotled waveform represents automated measurement. Solid waveform represents manual measurement laken at UHC ports. 


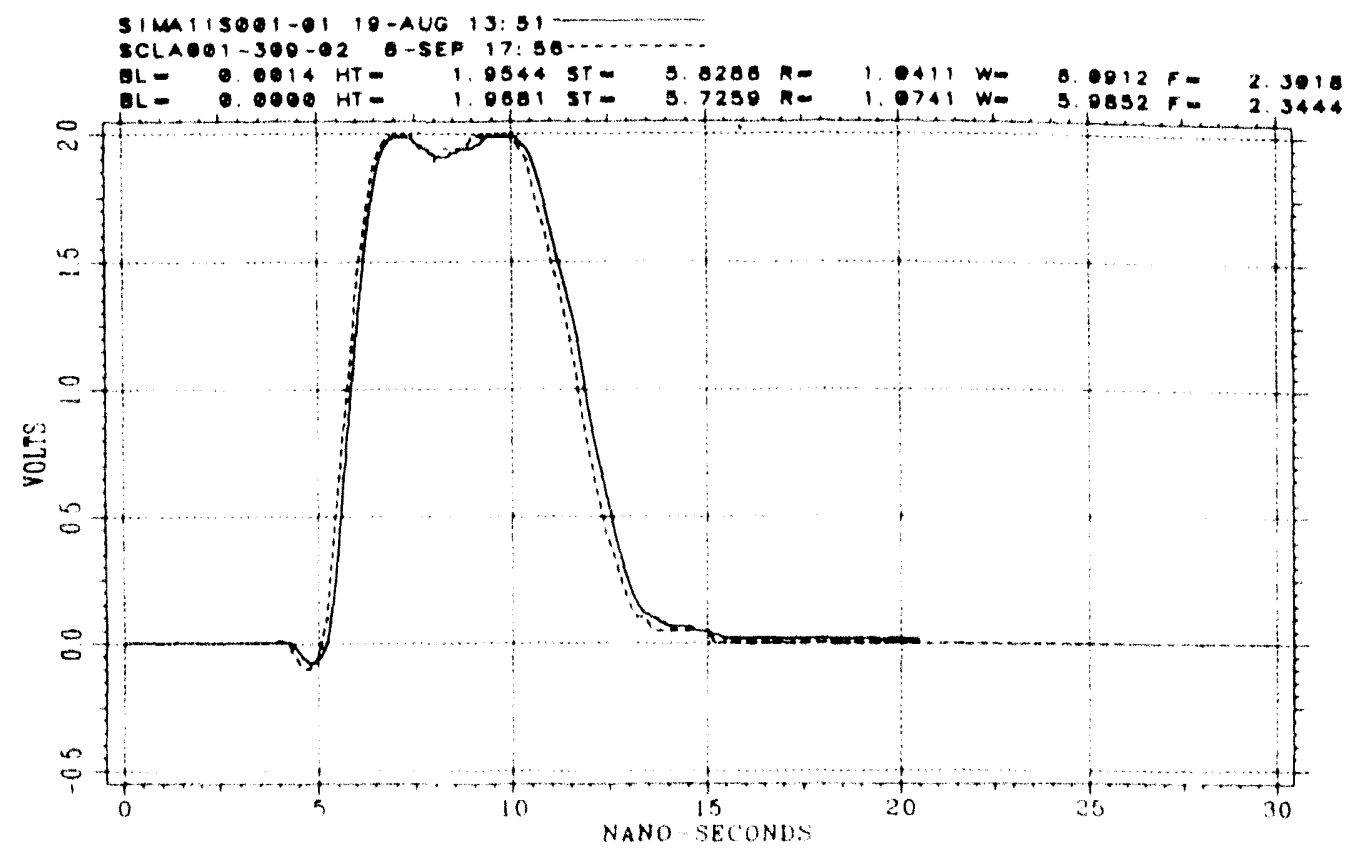

Fig. 9b.

Simulation channel 2.

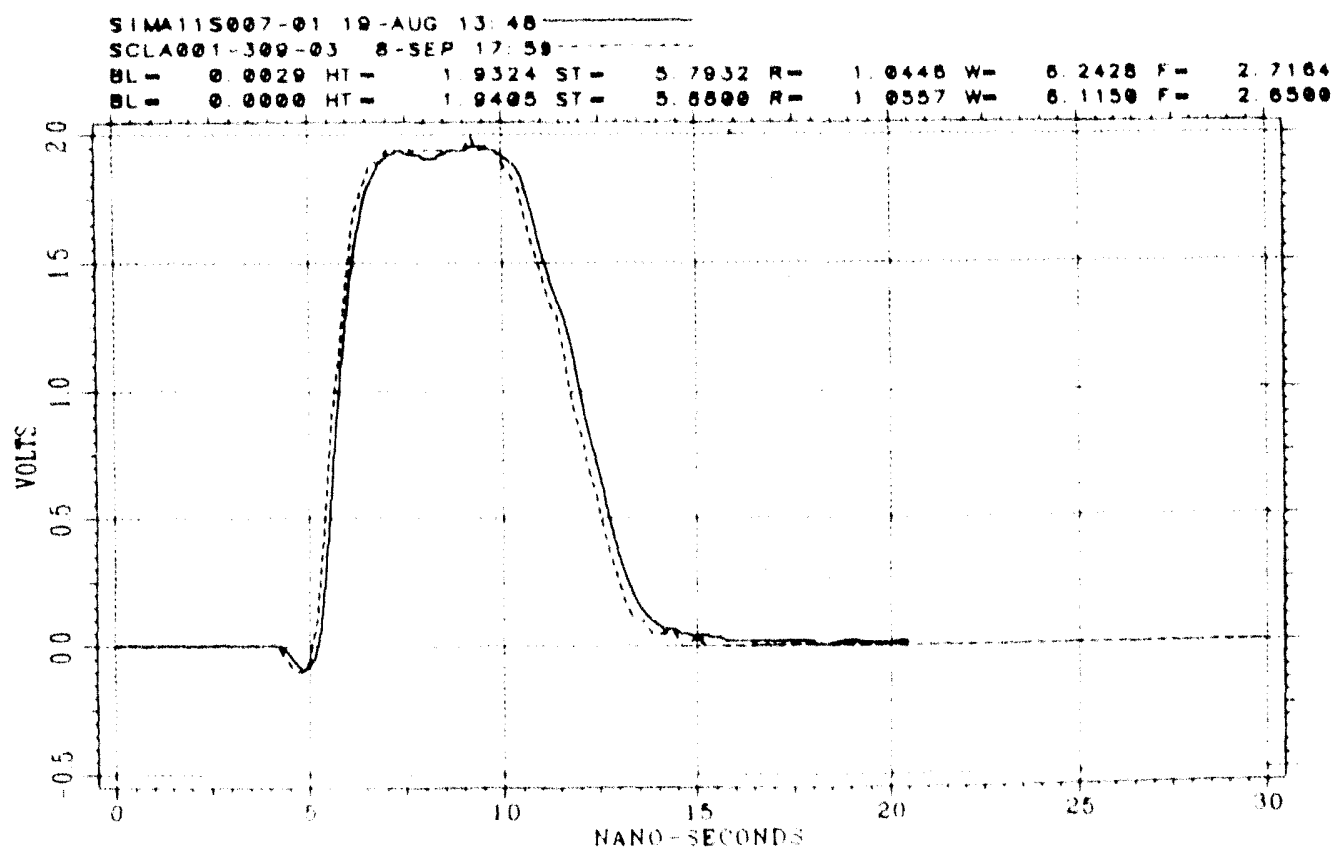

Fig. 9c.

Simulation channel 3. 


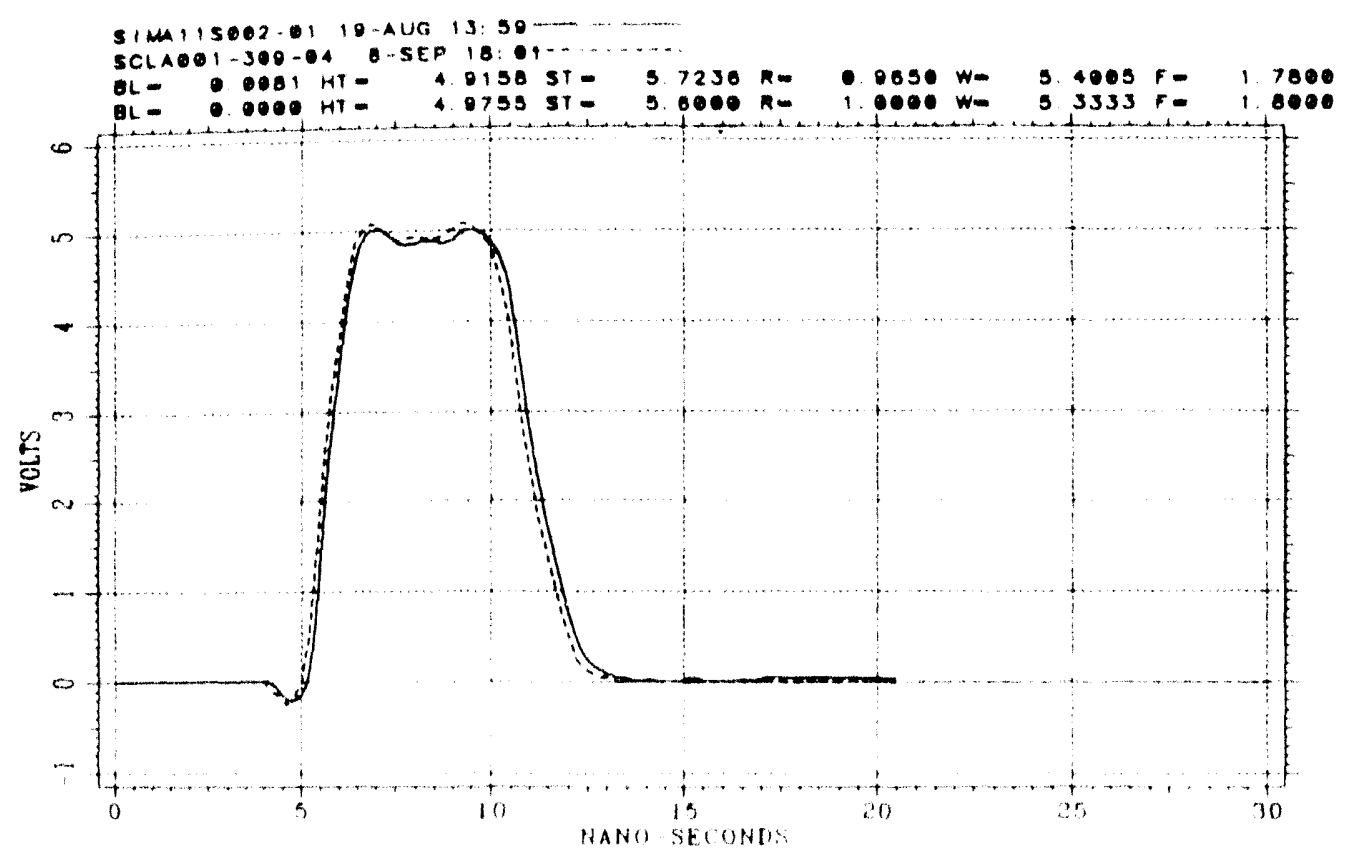

Fig. 9d

Simulation channel 4.

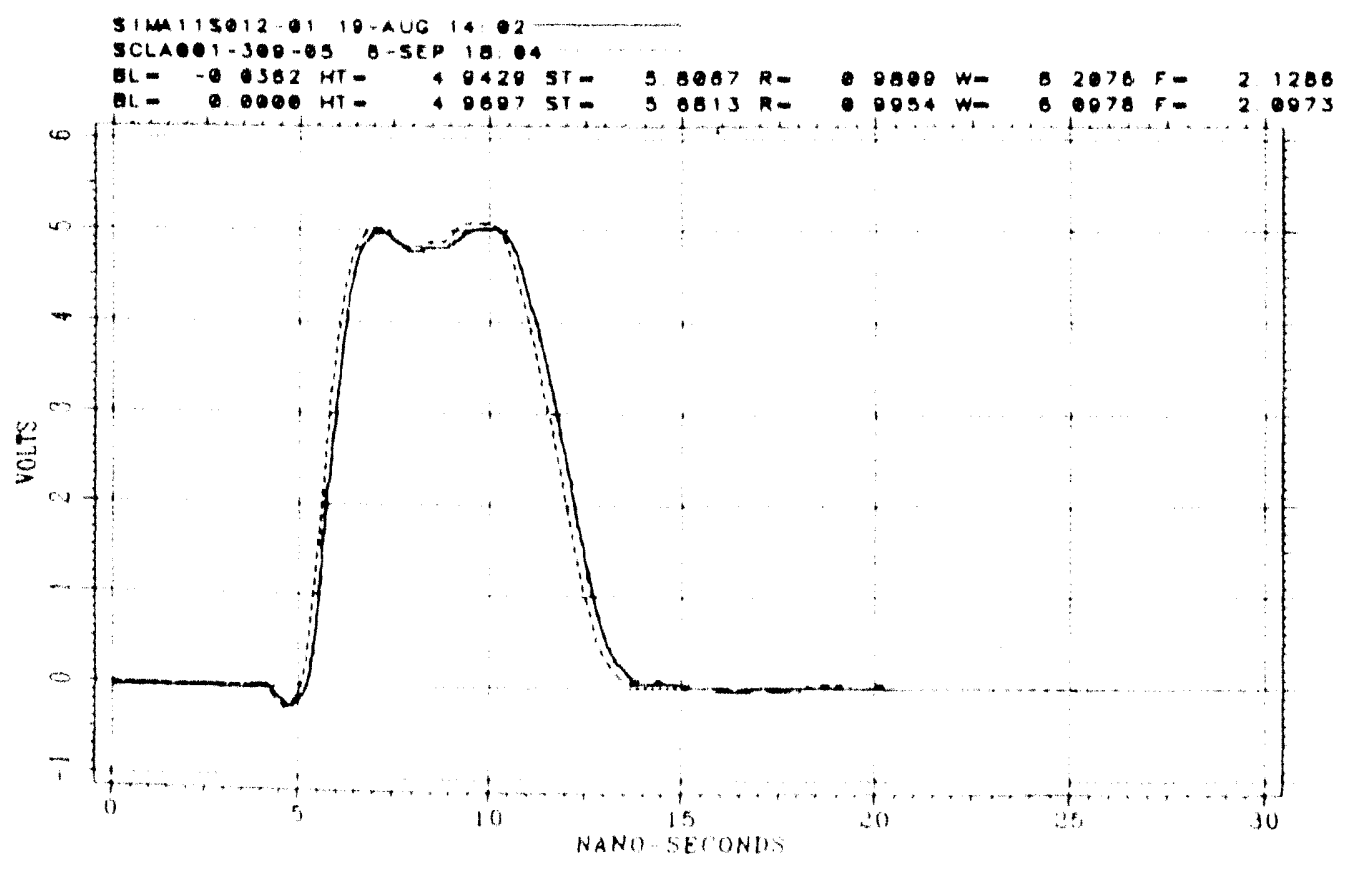

Fig. 9c.

Simulation channel 5 


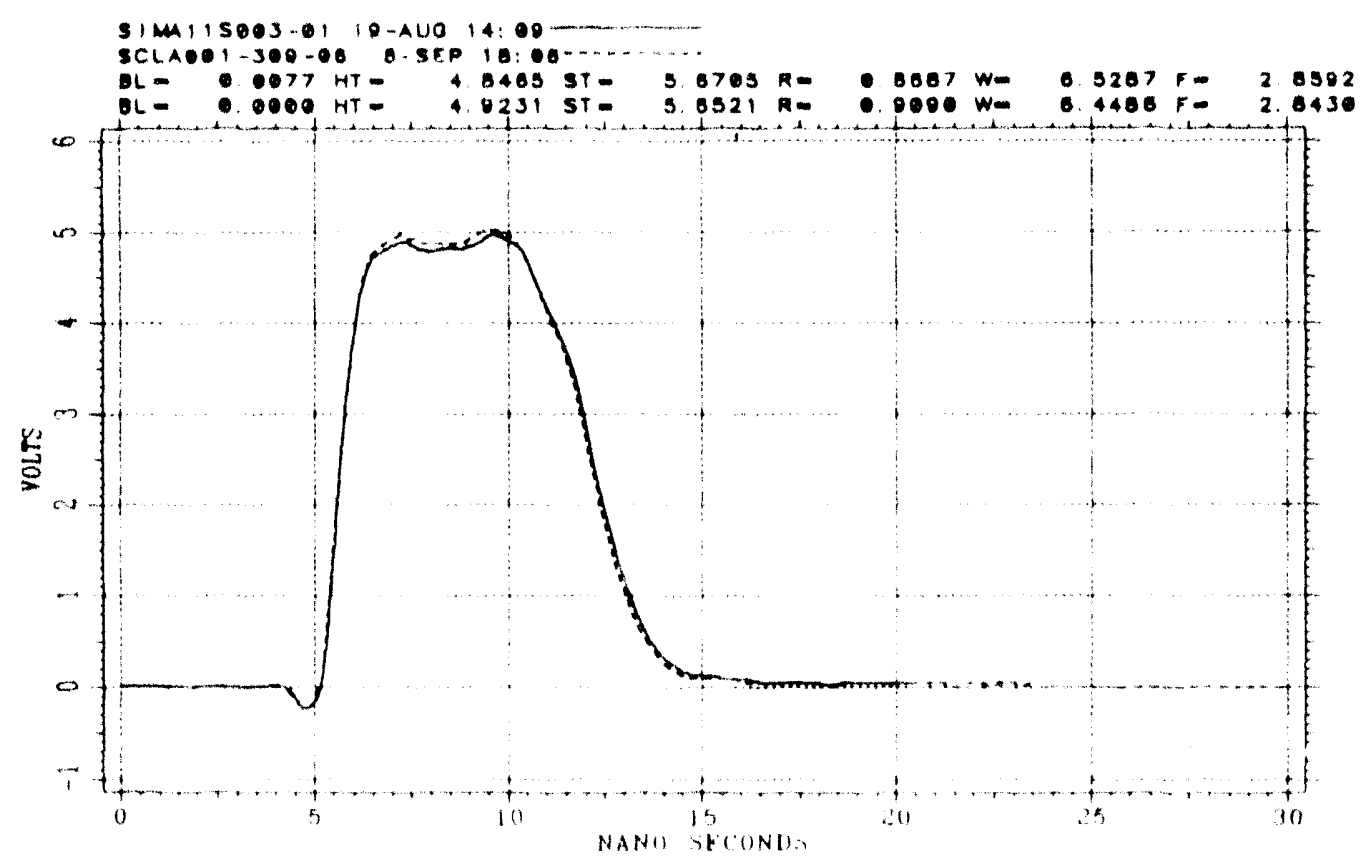

Fig. 91 .

Simulation chamnel 6 .

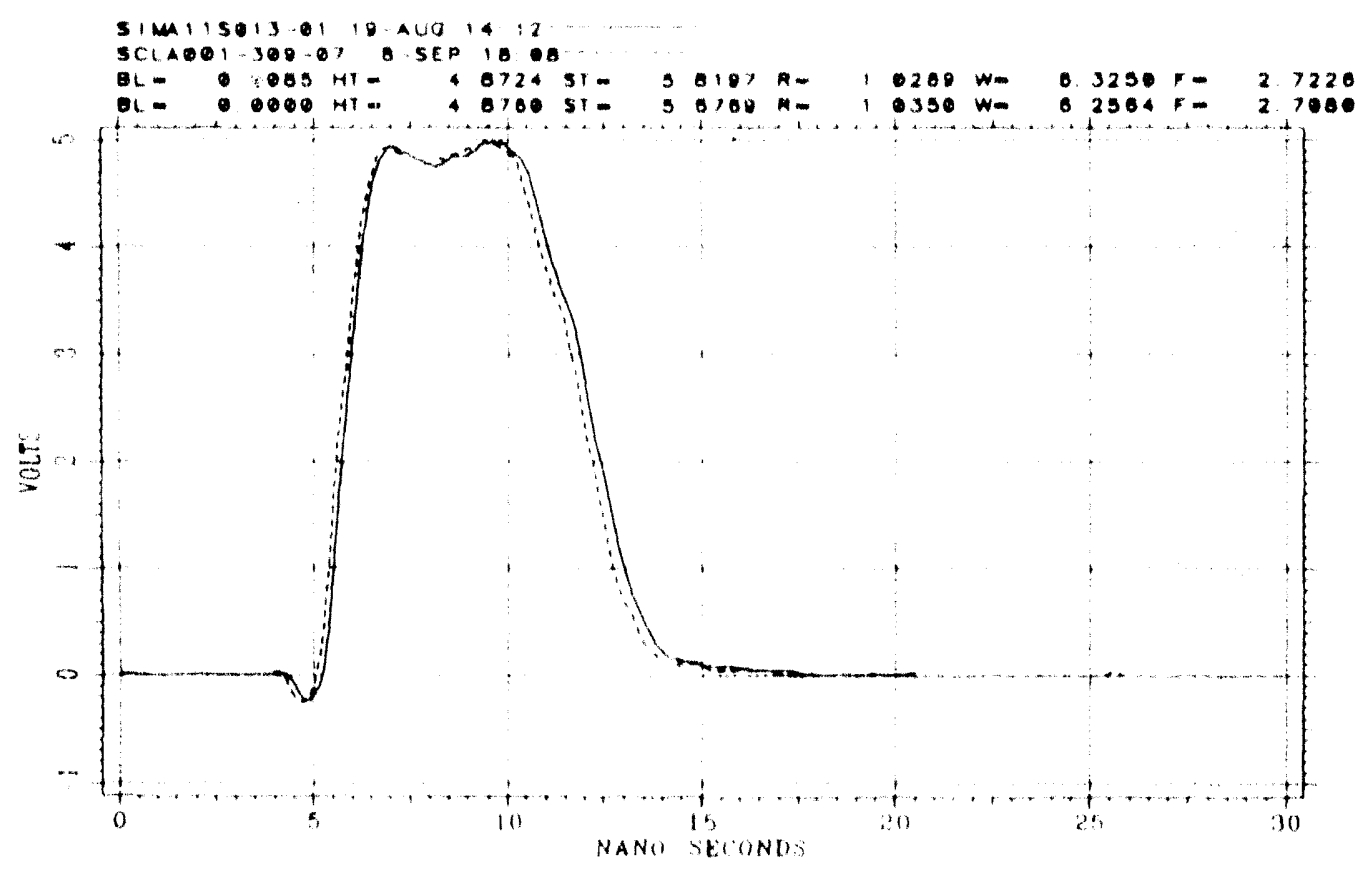

Fig. 9g.

Simulation channel 7 


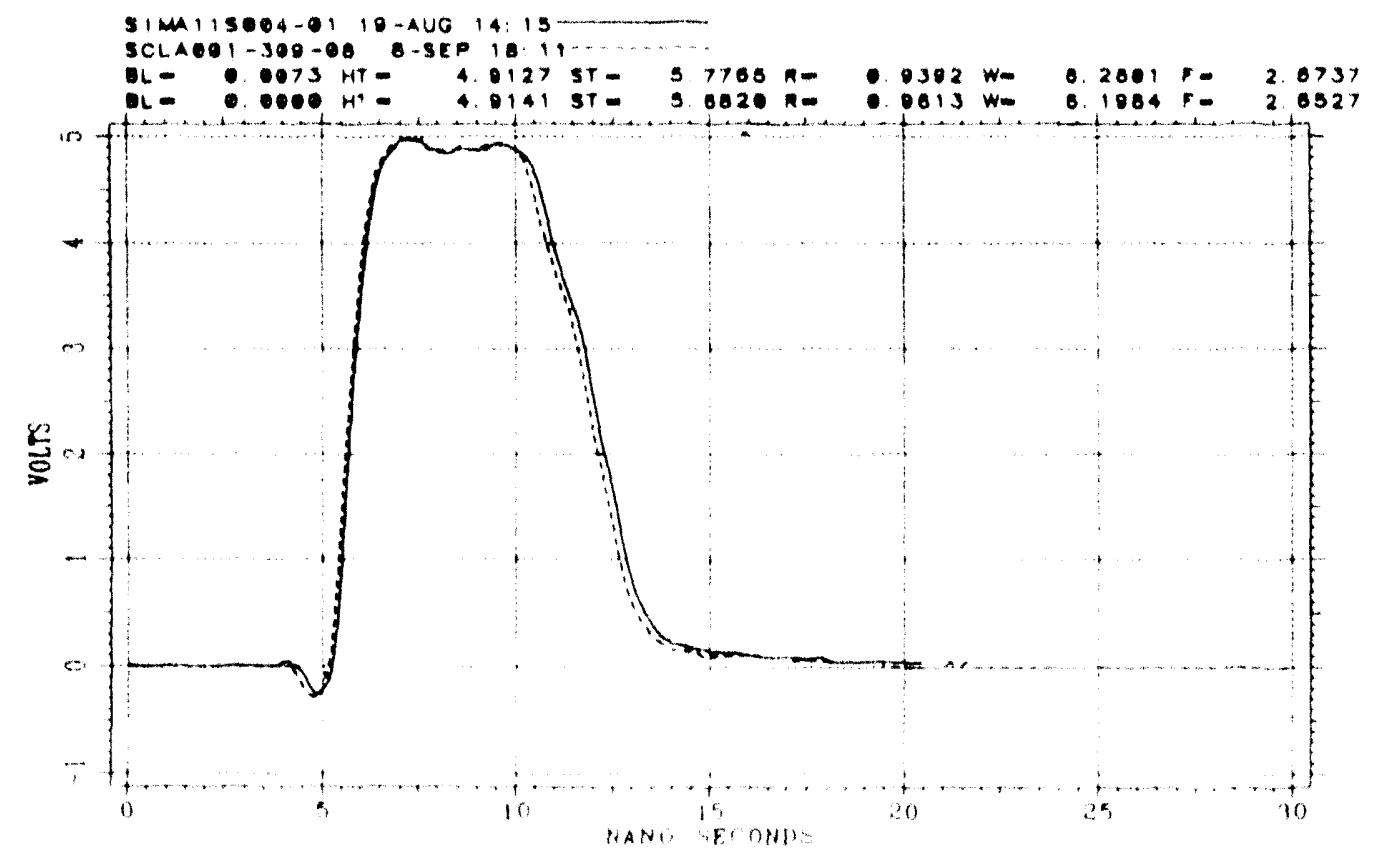

Fig. 9h.

Simulation chammel 8 .

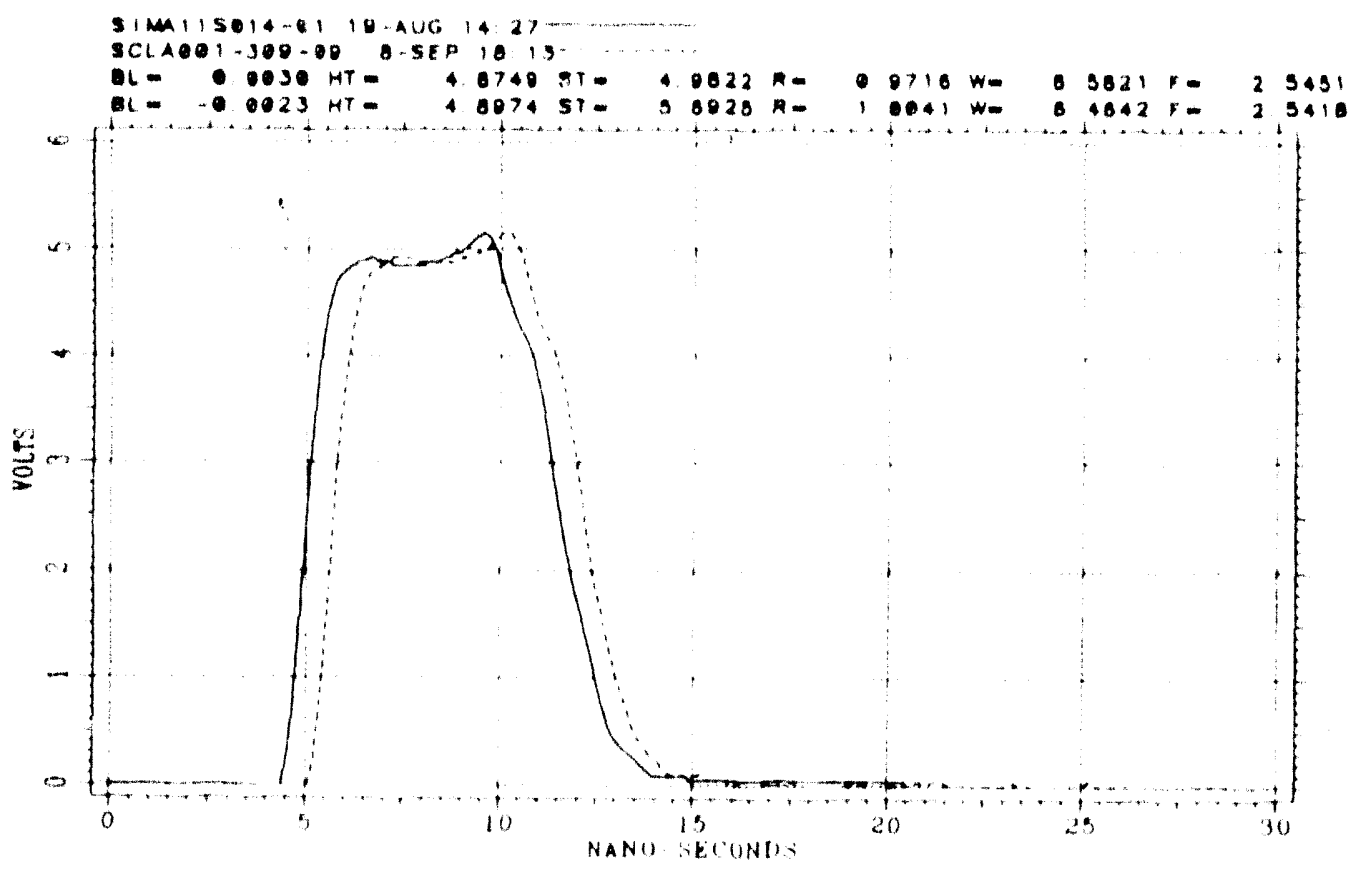

Fig. 9 i.

Simulation channel 9. 


\subsection{SOFIWARE IOFSC RIPIION}

Control of the Autodharacterization System is normally dome uphole in Bldg. $129(1)$ or on any graphic terminal that has terminal server ethernet access to the computer nework MAIN AUTOCHAR.EXE is the object like used to run on the terminal. Rumning MAIN AUTOCHAR IXE will bring up a series of memus to initialize the system. System operation is localed in the (HAN SEL subroutine which comes up atitomatically

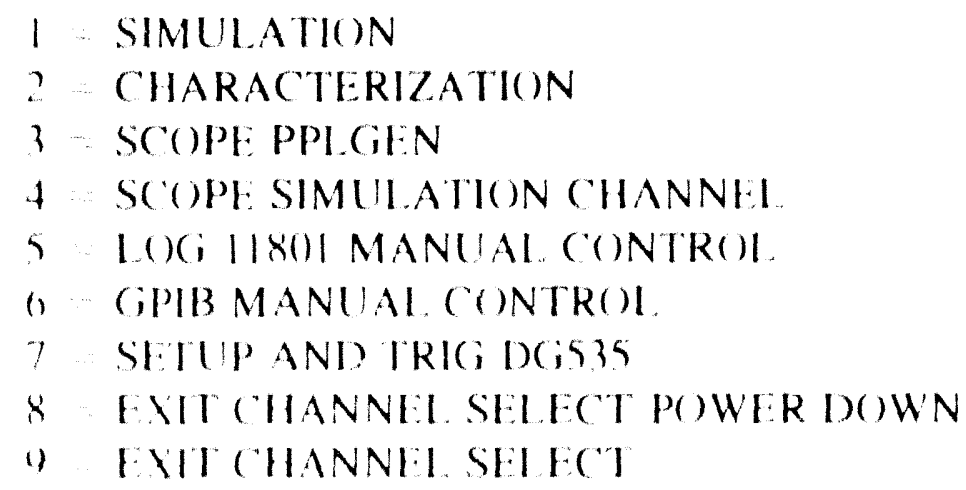

Tahk: 1

Aufodarakerisation combol menu for Hunters Trophy.

The comber menu allows the operator to select and execute a fiunction with minimum

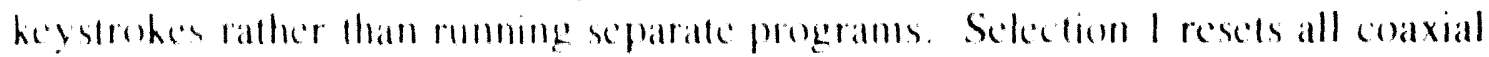
swithes except for the AC power combol. This allows all simulation signals to pass through the swikh matrix. Selection 2 yecress the operator for a chammel number and then routes the last pulse generater signal to the reguested channel (uphole cable). Selection 3 comeces the fast pulse generatur signal and trigger to the sampling seope Selection 4 yuerices the operator for a simulation chammel mumber and connects the sampling scope to the approprtate simmlater channel. Selection 5 records data from the sampling scope and filcs the data. This data file can be plotfed using DSPl. Selection

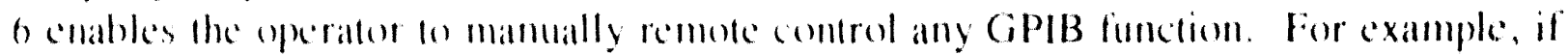
the operator wathled fo know the status of the AC power control switch, a command could be sent direclly on the bus and the reply read on the terminal. Selection 7 was infended 60 control the triggering of the simulation and chatacterisation via the DG535. This sekefion was not realy for Henkers Trophy because the process of operating the system was mol clearly defined. The DC535 was controlled mamually using manual GPIB control (schection on). Solection 8 opens all switches in the switch matrix

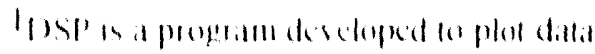


including the AC power control thus turning off the pulse generator, sampling scope and DC power to the switches.

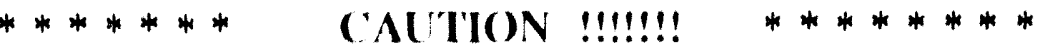

\section{CAUTION !!!!!!! ********}

SWITCHES IN THE HF 4447I A MODULES IN THE HP3488A

CONTROI.LER ARE L.ATCHING, THIS MEANS THAT IF THE

HP348RA IS P(OWERED DOWN, THE SWITCHES ARE NOT

RESET AND WILL NOT BE RESET UNTIL THE UNIT IS

POWERED UP. UPON POWER UP, AN AUTOMATIC

INITIALIZATION RESETS AI.I. SWITCHES

Selectiong exits from the CHAN SEL subroutime and allows exiling the control program whihoul altering switch seltings. This is useful in mouble shonting soffwart. plothing data and comparing and useful if there are compuler glitches requiring program restart.

A mulliwindow workstallon would mon DSP. ACETEST? and MAIN AUTOCHAR simmltameously in their reserefive window and under control of a single eperator MAIN AUTOCHAR combols switching and data reconding. ACETEST controls the 79) 2's and DSP is used lo plot recorded data.

\subsection{PIISF (IENERATOR MEAST REATENT}

Fig. 10 is a plof of a $1 \mathrm{kh}$ pulse from the Picosecond Pulse Lab fast pulse generator through the swith matrix and after installation downhole. The generator was set to oufput pulses of 50 ns at 10626 volts amplitude fo compensate for switch allemuation. Fig. 8 shows the swileh configuration for obtaining this record. The purpose of this is to view the oufput of the pulse generator by the operator before cable charackerization starts so the operater can verify amplitude and pulse width. Fach cable requires its own amplitude and pulse width which experimenters specify. Mone mature soffware will have to be developed to store presel amplitude and pulse duration seltings

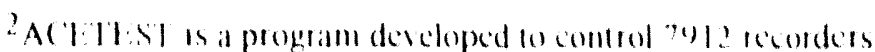




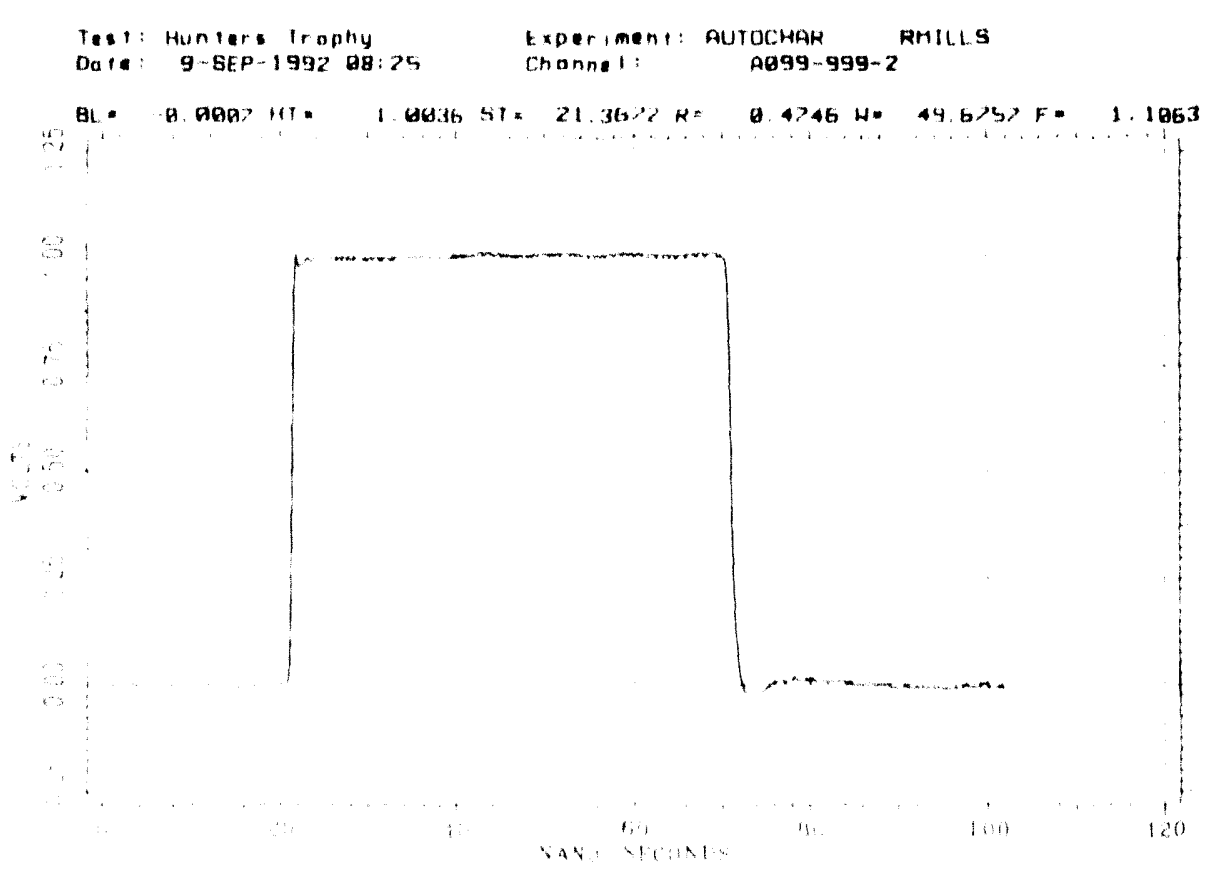

Fig, 10 .

Pulse from PPI last pulse generator, recorded from uphole, after downhole equipment installation.

for each cable to be characterized so operators can execule this process with a minimum of dala entry.

\subsection{CHARAC'IERI'LA'TION MEASUREMENT'}

Characterization on Hunters Trophy required a coordinated effort wilh recording room operators to operate two lerminals. This effort was impossible with the compressed schedule imposed. Personnel were working many overtime hours often after 10:(X) PM and, given the amount of work in necessary calibration, this experiment in characterization could not be successfully performed. However, the triggering of simulation was done uphole for simulation and this triggering is a large part of the characterizing process. Fig. 7 shows the switch configuration for characterization. The fast pulse generator would be set to trigger from the trigger input port which is initiated from the DG535. This is selection 7 of the MAIN AUTOCHAR menu.

\subsection{CONCLUSIONS}

The data plotted from simulation reveal that an operator can monitor simulation and pulse generator status from uphole. Also simulation can take place through coaxial 
switches with acceptable pulse degradation. The que stom remams ahout the practicality of characterization using a workstation. Given the circumstances of a compressed schedule on Hunters Trophy, and the limited number of channels it would seem that at system such as this would only be practical and cost effective in terms of money in two ways. First, the volume of channels to be characteried and simulated would have to be high of justify the system cost. And second, the process by which simulation and

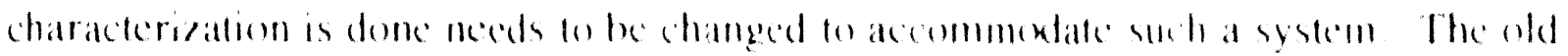
process of reguiring people uphoke and downhoke must be completely hanged and a

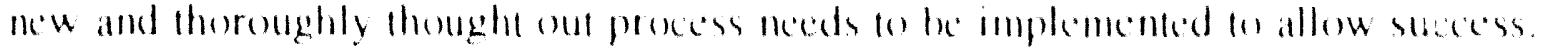
Preparation for many shots has harkened the old procese for cable chataderization and (hange will nof be casy.

\subsection{RECOMIMENIOATIONS}

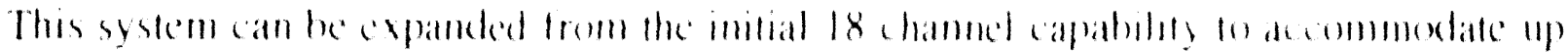

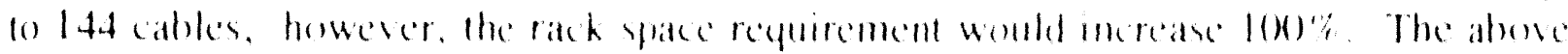

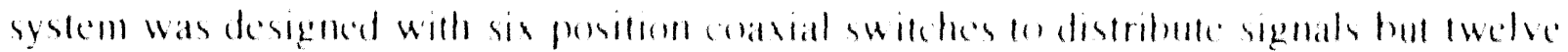

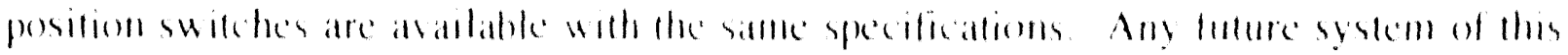

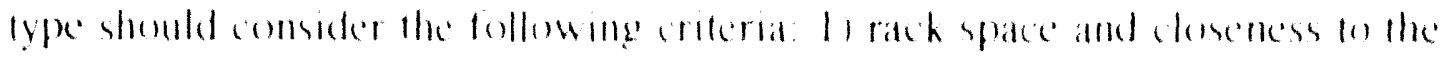

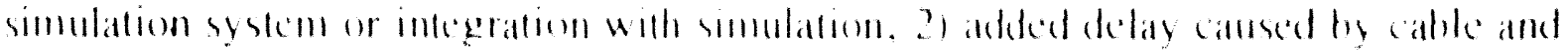

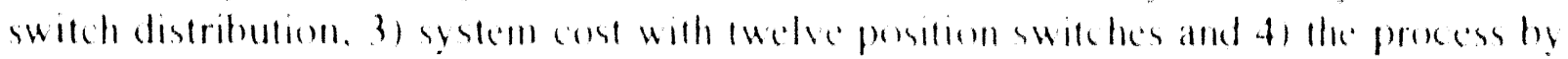
which this syslem is operaled 


\section{DISTRIBIITION}

1 Fich Command

Defence Nuclear Agency

Altn: FCTl (Goorge I.u)

Kirlland $A F B$

Albugucryic, NM 87117 5(X)

5 Defence Nuckar Agency

Alun FCTII) (Kiran Shah)

4420 Mikhell Si

North Las Vegas. NV 8901) 11

1 Allied Signal

Atlin: Frank Stcpaniak

4420 Mitchell Si

North Las Vegats, NV 89031
57141 Technical Library
17151 Technical Publications
10 70132 Document Processing for D)( E) (OSTI

18.5232 Commal Techmical Files

19305 M. J. Navrotil

19312 L. B. Bishop

19321 W. B Buycr

193.1 R. D. Adil

10321 L. D Baher

19321 R. B. Caudlll

19321 T. I. Downly

19321 R. E. Finch

19321 R. I Isidoro

$10321 \quad$ P. C. Kilcislner

19321 R. I. Kinchen

I 9.321 J.W. I

14321 L. Livingston

10321 P. F. Mokaly

6) 9321 R. A. Mills

14321 J. L. Rominc

l $9322 \quad$ C.W. Cook

I 9323 G. L. Oglo
19323 C. (․ Browne

I 9324 P. I. Nelson

I 9324 D. I. Bolding

I 9.324 W. I Kluestier

19324 F. I Raymond

19324 E. W Marsh (licis(i)

I 9324 B. I. Wohlbrand IECiN(i) 

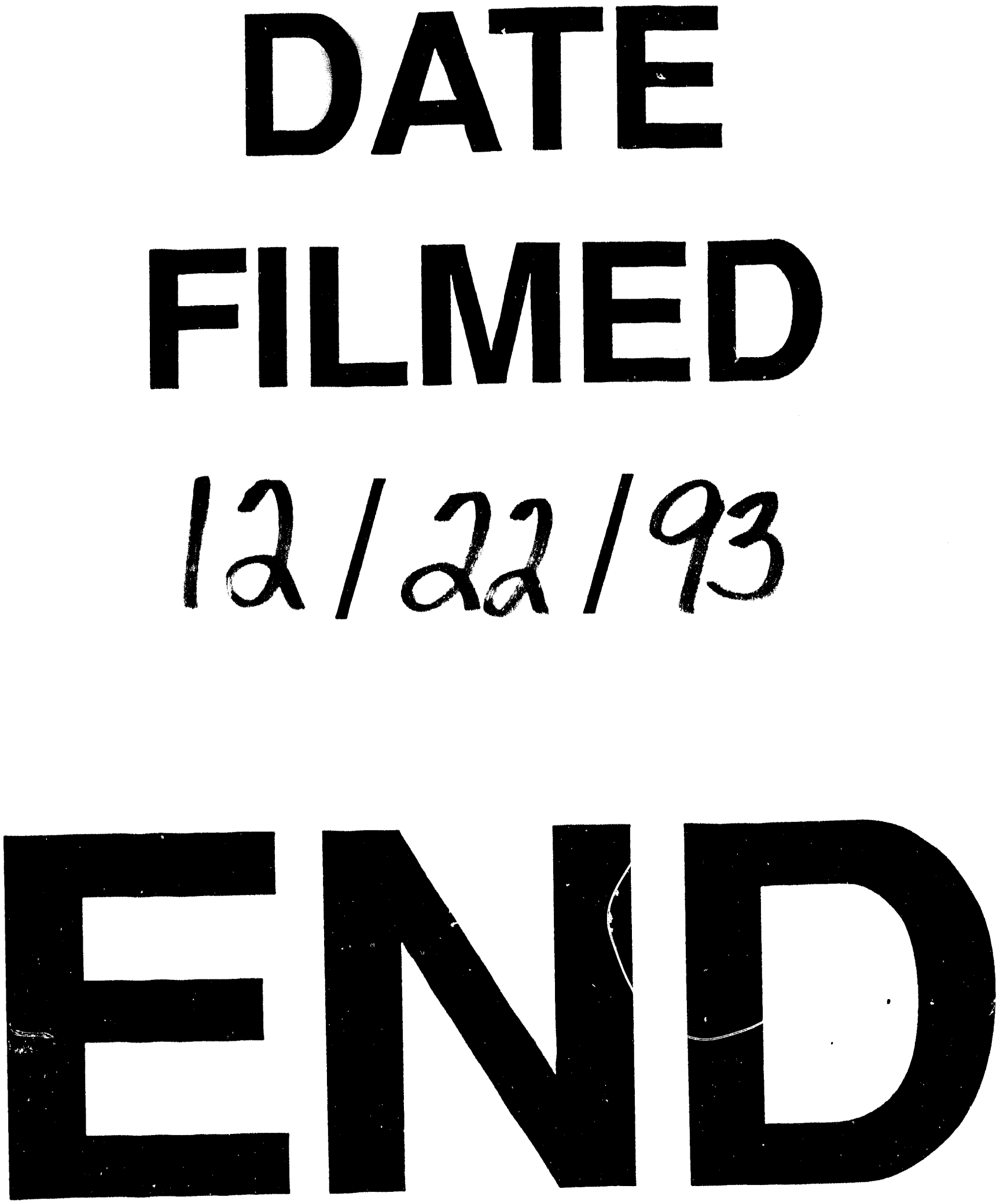
